\title{
WestVirginiaUniversity
}

THE RESEARCH REPOSITORY @ WVU

Graduate Theses, Dissertations, and Problem Reports

2003

\section{Winter habitat use of fishes in the Ohio River}

\author{
Benjamin Ernst Lenz \\ West Virginia University
}

Follow this and additional works at: https://researchrepository.wvu.edu/etd

\section{Recommended Citation}

Lenz, Benjamin Ernst, "Winter habitat use of fishes in the Ohio River" (2003). Graduate Theses, Dissertations, and Problem Reports. 1796.

https://researchrepository.wvu.edu/etd/1796

This Thesis is protected by copyright and/or related rights. It has been brought to you by the The Research Repository @ WVU with permission from the rights-holder(s). You are free to use this Thesis in any way that is permitted by the copyright and related rights legislation that applies to your use. For other uses you must obtain permission from the rights-holder(s) directly, unless additional rights are indicated by a Creative Commons license in the record and/ or on the work itself. This Thesis has been accepted for inclusion in WVU Graduate Theses, Dissertations, and Problem Reports collection by an authorized administrator of The Research Repository @ WVU. For more information, please contact researchrepository@mail.wvu.edu. 


\title{
WINTER HABITAT USE OF FISHES IN THE OHIO RIVER
}

\author{
Benjamin Ernst Lenz
}

\author{
Thesis submitted to the \\ Davis College of Agriculture, Forestry, and Consumer Science \\ at West Virginia University \\ in partial fulfillment of the requirements \\ for the degree of
}

\author{
Master of Science \\ in \\ Wildlife and Fisheries Resources
}

Stuart A. Welsh, Ph. D.

Kyle J. Hartman, Ph. D.

Alan J. Temple, Ph. D.

Department of Forestry

Morgantown, West Virginia

2003

Keywords: winter, juvenile, tributary, embayment, channel catfish (Ictalurus punctatus), freshwater drum (Aplodinotus grunniens), white bass (Morone chrysops)

Copyright 2003 Benjamin E. Lenz 


\section{ABSTRACT \\ Winter Habitat Use of Fishes in the Ohio River \\ Benjamin Ernst Lenz}

Winter is a critical period during which fishes may suffer increased mortality. To identify the habitats that fishes use in large rivers during winter conditions, we electrofished six habitat types in the Belleville Pool, Ohio River. We collected the greatest diversity and numbers of fishes in low-velocity tributary confluences when water temperatures were $>4{ }^{\circ} \mathrm{C}$. When water temperatures were $<4{ }^{\circ} \mathrm{C}$, certain species were collected in greater abundance in faster-velocity main channel and back channel habitats while other species continued to associate with lower flows in tributary mouths. Differing habitat use between species obscures broad generalizations about when and how fishes use overwintering refuges.

In an additional habitat sampled, an embayment, $85 \%$ of all fishes collected were juveniles. Centrarchids, rarely collected in the mainstem portion of the river, were one of the dominant fishes collected in the embayment. Protecting large river embayments may prove important for managing recreational sunfish fisheries.

Channel catfish, Ictalurus punctatus, and freshwater drum, Aplodinotus grunniens, the most abundant fishes collected in the Belleville Pool, exhibited growth comparable to other populations in temperate large rivers in eastern North America. Conversely, white bass, Morone chrysops, growth was slower compared to other populations, possibly explaining why none of the white bass individuals collected were harvestable size. Population growth and the probability of survival of all fishes may 
increase by protecting and enhancing tributary and embayment habitats in large rivers during winter. 
Dedicated to my wife Carmen 


\section{ACKNOWLEDGMENTS}

To those of you who helped me during the cold months of the year, John Howell, Kim Bjorgo, Gerry Balmert, Dave Wellman, Liz Osier, Jeremy Webster, Chris Nelson, Roy Martin, Dr. Stuart Welsh, Jon Niles, Elsa Lenz, Carmen Crisostomo-Lenz, and Jen Titus, when most others were warm and cozy, I thank you. To John Howell, whose patience proved worthy in crafting a sturdy vessel, I thank you. To my wife, Carmen, who suffered my absence, I thank you. To my mentors, Dr. Stuart Welsh, Dr. Kyle Hartman, and Dr. Alan Temple, I thank you. To George Seidel and Dr. John Sweka, for their statistical prowess, I thank you. To Dr. Pat Mazik, for her leadership, I thank you. To Becky Nestor, for her administrative help, I thank you. To the West Virginia Department of Natural Resources and the United States Army Corps of Engineers for their financial support of this project, I thank you. Last but not least, to Gary Batton for his ever-present humor and allowing us access to what we needed at the Bass Shack, I thank you. 
TABLE OF CONTENTS

$\underline{\text { PAGE }}$

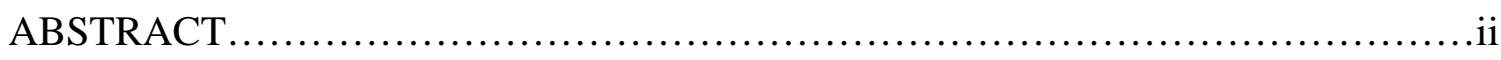

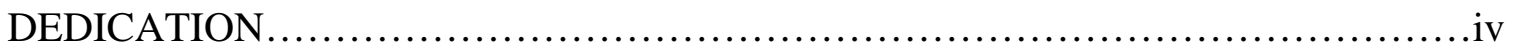

ACKNOWLEDGEMENTS .......................................................

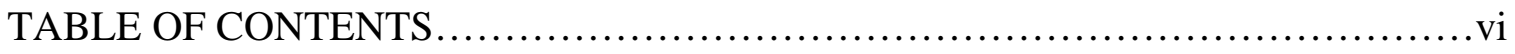

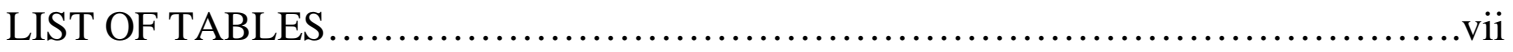

LIST OF FIGURES.................................................................iii

CHAPTER 1. Introduction and Literature Review.....................................1

CHAPTER 2. Winter Habitat Use by Fishes in a Large River.............................11

CHAPTER 3. Juvenile Use of a Large River Embayment during Winter.................40

CHAPTER 4. Growth Assessment of three Sport Fishes of the Ohio River................59

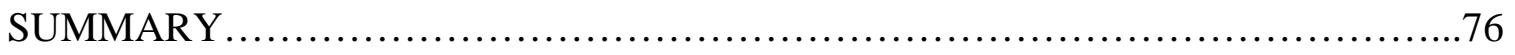

APPENDIX A: Fish caught per hour (CPUE) within each habitat type in the Belleville Pool, Ohio River.............................................78

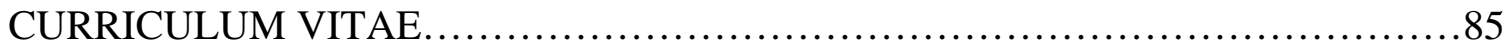




\section{LIST OF TABLES}

TABLE

$\underline{\text { PAGE }}$

1. Average abiotic conditions of all sites in six habitat types during six different sampling periods between February 16 through April 7, 2002 and December 12, 2002 through March 17, 2003 in the Belleville Pool, Ohio River. Standard deviations are in parentheses. Habitat types and abiotic variables with no values were not sampled during February 16 - 22, 2002 and the deep hole category with no standard deviation values only had one sample site during this period

2. Total number of individuals and juvenile proportion of the total for each fish species collected by pulsed DC electrofishing in the Little Sandy Creek embayment, West Virginia, during December 15, 2002 through March 17, 2003. Values in parentheses are the proportion of the total individuals represented by juveniles for that sampling date....

3. The length range, mean length, and variance at age for white crappies collected by pulsed DC electrofishing in the Little Sandy Creek embayment, West Virginia, during December 15, 2002 through March 17, 2003.

4. Mean length-at-age of channel catfish, freshwater drum, and white bass collected in the Belleville Pool, Ohio River during February 17 through April 7, 2002 and December 12, 2002 through March 17, 2003. Variances are in parentheses; no values indicate only one individual for that age group was

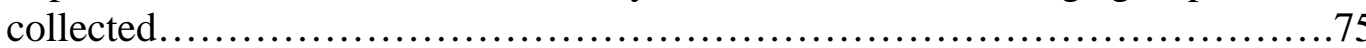




\section{LIST OF FIGURES}

\section{$\underline{\text { FIGURE }}$}

1. The proportion of the total catch of each species among habitat categories. Data are separated by water temperatures $>4{ }^{\circ} \mathrm{C}(\mathrm{A}), 3<4{ }^{\circ} \mathrm{C}(\mathrm{B})$, and $<3{ }^{\circ} \mathrm{C}$ (C) within Belleville Pool, Ohio River, during February 17 through April 7, 2002 and December 12, 2002 through March 17, 2003. Sites are abbreviated as bc (back channel), dh (deep hole), ih (island head), it (island tail), mc (main channel), and $\operatorname{tr}$ (tributary). Fish species are abbreviated as D. cepedianum (gizzard shad), H. tergisus (mooneye), M. storeriana (silver chub), C. carpio (river carpsucker), I. bubalus (smallmouth buffalo), I. punctatus (channel catfish), M. chrysops (white bass), M. saxatilis x chrysops (hybrid striped bass), and A. grunniens (freshwater drum).

2. Water temperature (broken line), stage height (solid line), and sampling session dates (x) in Belleville Pool, Ohio River, during December 1, 2001 through April 14, 2002 (A) and December 1, 2002 through April 14, 2003 (B)...30

3. The number of species in each habitat category collected in the Belleville Pool during December 1, 2001 through April 14, 2002 and December 1, 2002 through April 14, 2003. Sites are abbreviated as ih (island head), it (island tail), trib (tributary), mc (main channel), bc (back channel), and dh (deep hole)........32

4. Triplot from canonical correspondence analysis (CCA) of species abundance, sites, and abiotic variables from February 16, 2002 through April 7, 2002 (A) and December 12, 2002 through January 19, 2003 (B) in the Belleville Pool, Ohio River. Sites are symbolized as $\diamond$ (tributary), + (island head), $\circ$ (island tail), $\square$ (back channel), $\Delta$ (main channel), and $\mathrm{x}$ (deep hole). Abiotic variables are depth, specific conductivity (Cond), temperature (Temp), turbidity (Turb), and water velocity (Flow). Species are numbered as 1) I. bdellium, 2) D. cepedianum, 3) H. tergisus, 4) Cyprinus carpio, 5) M. storeriana, 6) N. atherinoides, 7) Carpiodes carpio, 8) C. cyprinus, 9) C. velifer, 10) M. erythrurum, 11) M. macrolepidotum, 12) I. bubalus, 13) I. punctatus, 14) P. olivaris, 15) $M$. chrysops, 16) M. chrysops x saxatilis, 17) A. rupestris, 18) P. nigromaculatus, 19) M. punctatus, 20) L. macrochirus, 21) S. canadense, 22) S. vitreum, and 23) A. grunniens.

5. The captured sonar image from Bull Creek on January 11, 2003, when the single highest total catch of fishes occurred. Black streak like blotches are individual

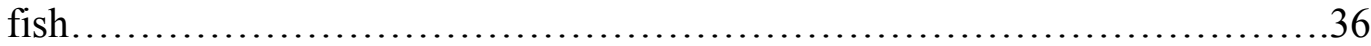


6. Length-frequencies of gizzard shad, bluegill, emerald shiner, white crappie, and orangespotted sunfish collected by pulsed DC electrofishing in the Little Sandy Creek embayment, West Virginia, during December 15, 2002 through March 17,

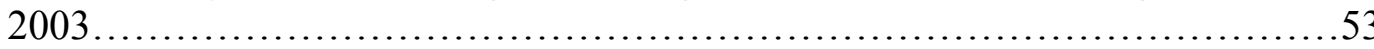

7. The age frequencies of channel catfish, freshwater drum, and white bass collected in the Belleville Pool, Ohio River during February 17 through April 7, 2002 and December 12, 2002 through March 17, 2003 _...........................................68

8. The von Bertalanffy growth curves of channel catfish, freshwater drum, and white bass collected in the Belleville Pool, Ohio River................................................70

9. The allometric growth of channel catfish, freshwater drum, and white bass collected in the Belleville Pool, Ohio River.....................................72 


\section{Chapter 1. Introduction to Winter Habitat Use of Fishes in Large Rivers, Juvenile Mortality during Winter, and the Use of Age and Growth Information in Assessing the Condition of Sport Fisheries.}

\section{Overview}

This manuscript attempts to define which habitats large river fishes use to survive during winter. We identify the specific abiotic conditions existing in habitats fishes use during winter in the upper Ohio River. Chapter 2 of this manuscript discusses the results from the winter habitat study of the mainstem portion of the Ohio River. Chapter 3 reveals the use of embayments by juvenile fishes during winter in the upper Ohio River. Lastly, Chapter 4 summarizes the results from the age and growth study of three popular game fishes collected during the winter habitat study.

Winter survival of fishes in large rivers

Winter is a critical period during which freshwater fishes suffer increased mortality (Hubbs and Trautman 1935; Cunjak 1988; Garvey et al. 1998). Young-of-year (YOY) fishes often experience the highest mortality during winter (Toneys and Coble 1979; Ludsin and DeVries 1997; Garvey et al. 1998). Yet, fishes of all ages suffer increased mortality during winter. To increase their probability of survival, fish use certain habitats during winter. Fishes in large rivers are no exception to this rule (Johnson et al. 1998).

In large temperate river systems, extremely low water temperatures during winter coupled with high flows increase mortality rates of fishes (Bodensteiner and Lewis 1992; Lyons 1997). Low levels of dissolved oxygen (D. O.) also increase mortality of fishes, and occur typically during ice-cover of backwater areas (Raibley et al. 1997). Many fishes forage infrequently during cold winter extremes, and select refuges that minimize 
energy depletion (Crawshaw 1984; Carlson 1992). Fishes often increase fat-reserves before winter; hence, reducing mortality associated with energy depletion (Fullerton et al. 2000). However, energy reserves may not suffice given long winters or energy expenditures due to disturbance, such as variation in river flows or boat traffic (Nielsen et al. 1986). Past research has shown which abiotic conditions large river fishes prefer to minimize mortality during winter.

$\underline{\text { Abiotic conditions that limit fish survival during winter }}$ Temperature and flow

During winter, riverine fishes select habitats with relatively high temperatures and low flows. Riverine fishes overwinter in velocity shelters (Logsdon 1993; Bodensteiner and Lewis 1994; Johnson et al. 1998) and areas with warmer temperatures and lower flows than mainstem river sections, such as off-channel coves, marinas, embayments and industrial warm-water outflows (Sheehan et al. 1990; Knights et al. 1995; Gent et al. 1995; Raibley et al. 1997). Also, backwater areas with relatively warmer temperatures and lower flows provide winter habitats (Bodensteiner and Lewis 1992; Raibley et al. 1997; Sheehan and Rasmussen 1999). By occupying favorable habitats during winter, fishes avoid the stresses of variable flow velocity in the main channel portion of large rivers.

Sheehan et al. (1990) examined temperature and flow requirements for several fishes common in the Ohio River, such as gizzard shad, Dorosoma cepedianum, channel catfish, Ictalurus punctatus, and freshwater drum, Aplodinotus grunniens. Gizzard shad, channel catfish, and freshwater drum occupy relatively low velocity areas during winter (Heese and Newcomb 1982; Newcomb 1989; Sheehan et al 1990; Logsdon 1993; 
Bodensteiner and Lewis 1994). Gizzard shad are vulnerable to winter die-offs during low water temperatures (Miller 1960). Some fishes experiencing extreme low temperatures suffer cold shock (Cichra et al. 1982). These fish lose their ability to maintain their position in a preferred habitat and can be swept downstream to open channel habitats, reducing their chances of survival (Sheehan et al.1990; Bodensteiner and Lewis 1994). Sheehan et al. (1990) reported temperature preferences of $>4{ }^{\circ} \mathrm{C}$ for many species in large rivers, such as green sunfish, Lepomis cyanellus, bluegill, Lepomis macrochirus, and freshwater drum. Some species, such as channel catfish, black crappie, Pomoxis nigromaculatus, and walleye, Stizostedion vitreum, can maintain swimming abilities at temperatures $<4{ }^{\circ} \mathrm{C}$ (Sheehan et al. 1990). Temperature and flow preferences during winter and swimming abilities during low temperatures are unknown for most riverine fishes.

\section{Dissolved oxygen}

Abiotic factors other than water temperature and flow velocity can influence the suitability of winter habitats. Backwater areas can become anoxic and unsuitable as overwintering areas (Bodensteiner and Lewis 1992; Knights et al. 1995; Johnson et al. 1998). Low D. O. levels can result in fish die-offs when backwater areas become isolated from the main channel during low water levels in winter (Raibley et al. 1997). In the West Virginia section of the Ohio River, dissolved oxygen is reduced by water pollution near cities, but normally remains above critical levels (Pearson and Krumholz 1984). In the upper Ohio River, the availability and quality of backwater habitat typical of larger rivers such as the Missouri and Mississippi is limited and largely unavailable for fishes. The steep topography of the riparian zone restricts lateral movement of waters outside of 
the main channel. Embayments are the habitat type in the upper Ohio River most similar to lower elevation large river backwaters.

\section{$\underline{\text { Habitats available to fishes in the upper Ohio River during winter }}$}

The abiotic conditions of a particular habitat type may make them unsuitable for use by fishes during winter. As stated above, extreme and varying conditions during winter can increase mortality in fishes. To survive, fishes must choose habitats that offer refuge from the extreme conditions of winter. Habitats available to fishes during winter vary in their physical and chemical characteristics. A combination of physiochemical conditions, such as low-flow velocities and warmer temperatures, may offer the best refuge to overwintering fishes, yet these conditions can vary temporally, forcing fishes to use more than one specific habitat during winter.

Nine habitat types classified as main channel, deep hole, back channel, island head, island tail, tributary, wing dam, embayment, and tailwater are available for sampling in the upper Ohio River. Vallazza et al. (1994) and Cray (1999) discussed similar habitats, and our classification scheme is further described below. Main channel habitats are the open water portion of the river used as commercial navigation routes, and typically have shallow near-shore areas and deeper mid-channel sections. Deep hole habitats are relatively deep areas created by dredging or natural scour within main channel or back channel areas. Back channels, island head, and island tail habitats are associated with islands. Back channel habitats are also open waters, but are not typically used for barge navigation and occur between an island and the mainland. Habitats near the upstream and downstream ends of each island are island head and island tail habitats, respectively. Tributary habitats are located, specifically, where the joining waters form a 
confluence with the mainstem of the Ohio River. Wing dams (and other artificial flow barriers) create near-shore habitats with low water velocities. Tailwater habitats are the open often-turbulent water immediately below a dam. Embayment habitats are shallow bay-like areas connected to the main channel by a tributary or artificial channel.

$\underline{\text { Juvenile survival during winter }}$

Survival probability of fishes during winter often increases with body size (Hubbs and Trautman 1935; Cunjak 1988). Juvenile and YOY (young-of-year) individuals suffer increased mortality during winter compared to larger individuals (Toneys and Coble 1979; Ludsin and Devries 1997; Garvey et al 1998). Due to the higher loss of young individuals, winter is a critical period for recruitment into a population (Oliver et al. 1979; Toneys and Coble 1979; Miranda and Hubbard 1994). Limiting exposure to severe winter conditions allows fishes to persist through winter. Juvenile fishes should occupy habitats that are favorable for increasing the probability of survival during winter.

\section{Embayments}

Embayment habitats offer critical overwintering refuge for fishes of all ages in large river systems. Embayments are shallow bay-like areas connected to the main channel by a tributary or artificial channel. Backwaters are similar in morphology and function as embayments, but embayments receive input (water, sediment, and aquatic organisms) from both associated tributaries and the riverine system. Backwaters only receive input from their associated river (Cray 1999). Similar to backwaters, embayments offer relatively high temperatures and low flows during winter. These velocity shelters are favorable for overwintering riverine fishes (Logsdon 1993;

Bodensteiner and Lewis 1994; Johnson et al. 1998). The warmer temperatures and lower 
flows of embayments are often more benign than mainstem river conditions, offering fishes a refuge to escape the harsh conditions of winter (Sheehan et al. 1990, Knights et al. 1995, Gent et al. 1995; Raibley et al. 1997). These favorable conditions in embayments are optimal for overwintering fishes, especially juveniles, since they are most likely to suffer increased mortality during winter.

Importance of age and growth information about sport fisheries

Fish length-at-age estimates are important information used to assess the status of a fishery. The age of a fish can be determined in many ways. Bony parts of the fish such as otoliths, pectoral spines, and vertebrae can all be sectioned (cut) and, by simply counting the growth rings of the section, the reader can estimate the age of an individual. Regardless of the method used to determine ages of fishes, the information gathered yields important insight into age-related growth rates and the relative numbers of juvenile and mature fish in a population (DeVries and Frie 1996). The average size and size variation at different ages over several years can be used to determine growth patterns of a fish population over time or compare it with other populations. Changes in these measurements can be normal or may reflect unsuitable environmental conditions.

Fishery managers also use length and weight data as another method of assessing population condition. The sizes of individuals in a population also reflect growth rates. Knowing the abundance of certain sizes of fishes is important for evaluating the ability of a recreational fishery to support exploitation (Anderson and Neumann 1996). Harvest of recreational fisheries is often regulated by size limits. If few legal-sized individuals are available for harvest, it may be due to unfavorable conditions, which come in many forms (overharvest, pollution, competition for limited resources, overabundance, and more). If 
unhealthy conditions persist, fishery managers implement plans to improve the status of a fishery to make it viable for harvest. Without age and growth information, fishery managers would have difficulty in determining the status of sport fish populations. 


\section{Literature cited}

Anderson, R. O., and R. M. Neumann. 1996. Length, weight, and associated structural indices. Pgs. 447-482 in Fisheries techniques, $2^{\text {nd }}$ edition. B. R. Murphy and D. W. Willis, editors. American Fisheries Society, Bethesda, Maryland.

Bodensteiner, L. R., and W. M. Lewis. 1992. Role of temperature, dissolved oxygen, and backwaters in the winter survival of freshwater drum (Aplodinotus grunniens) in the Mississippi River. Canadian Journal of Fisheries and Aquatic Sciences 49: 173-184.

Bodensteiner, L. R., and W. M. Lewis. 1994. Downstream drift of fishes in the upper Mississippi River during winter. Journal of Freshwater Ecology 9: 45-56.

Carlson, D. M. 1992. Importance of wintering refugia to the largemouth bass fishery in the Hudson River estuary. Journal of Freshwater Ecology 7(2): 173-180.

Chichra, C. E., W. H. Neill, and R. L. Noble. 1982. Differential resistance of northern and Florida largemouth bass to cold shock. Proceeding of the Annual Conference of the Southeastern Association of Fish and Wildlife Agencies 34: 19-24.

Crawshaw, L. I. 1984. Low temperature dormancy in fish. American Journal of Physiology 246: 479-486.

Cray, D. C. 1999. The influence of geomorphology on fish assemblages of Ohio River embayments. M.S. Thesis. The Ohio State University, Columbus, Ohio.

Cunjak, R. A. 1988. Physiological consequences of overwintering in streams: the cost of acclimatization? Canadian Journal of Fisheries and Aquatic Sciences 45: 443452.

DeVries, D. R., and R. V. Frie. 1996. Determination of age and growth. Pgs. 483-512 in Fisheries techniques, $2^{\text {nd }}$ edition. B. R. Murphy and D. W. Willis, editors. American Fisheries Society, Bethesda, Maryland.

Fullerton, A. H., J. E. Garvey, R. A. Wright, and R. A. Stein. 2000. Overwinter growth and survival of largemouth bass: interactions among size, food, origin, and winter severity. Transactions of the American Fisheries Society 129: 1-12. 
Garvey, J. E., R. A. Wright, and R. A. Stein. 1998. Overwinter growth and survival of age-0 largemouth bass (Micropterus salmoides): revisiting the role of body size. Canadian Journal of Fisheries and Aquatic Sciences 55: 2414-2424.

Gent, R., J. Pitlo, Jr., and T. Boland. 1995. Largemouth bass response to habitat and water quality rehabilitation in a backwater of the upper Mississippi River. North American Journal of Fisheries Management 15: 784-793.

Heese, L.W., and B. A. Newcomb. 1982. On estimating the abundance of fish in the upper channelized Missouri River. North American Journal of Fisheries Management 2: 80-83.

Hubbs, C. L., and M. B. Trautman. 1935. The need for investigating fish conditions in winter. Transactions of the American Fisheries Society 65: 51-56.

Johnson, B. L., B. C. Knights, J. W. Barko, R. F. Gaugush, D. M. Soballe, and W. F. James. 1998. Estimating flow rates to optimize winter habitat for centrarchid fish in Mississippi River (USA) backwaters. Regulated Rivers Research and Management 14: 499-510.

Knights, B. C., D. L. Johnson, and M. H. Sandheinrich. 1995. Responses of bluegills and black crappie to dissolved oxygen, temperature, and current in backwater lakes of the Upper Mississippi River during winter. North American Journal of Fisheries Management 15: 390-399.

Logsdon, D. E. 1993. Suitability of side channel border and wing dam habitats for fishes overwintering in Pool 26 of the Mississippi River. M.S. Thesis, Southern Illinois University, Carbondale, Illinois.

Ludsin, S. A., and D. R. DeVries. 1997. First-year recruitment of largemouth bass: the inter-dependency of early life stages. Ecological Applications 7: 1024-1038.

Lyons, J. 1997. Influence of winter starvation on the distribution of smallmouth bass among Wisconsin streams: a bioenergetics modeling assessment. Transactions of the American Fisheries Society 126: 157-162.

Miller, R. R. 1960. Systematics and biology of the gizzard shad (Dorosoma cepedianum) and related fishes. Fishery Bulletin 60: 371-392. 
Miranda, L. E., and W. D. Hubbard. 1994. Winter survival of age-0 largemouth bass relative to size, predators, and shelter. North American Journal of Fisheries Management 14: 773-780.

Nielsen, L. A., R. J. Sheehan, and D. J. Orth. 1986. Impacts of navigation on riverine fish production in the United States. Polish Archives of Hydrobiology 33: 277294.

Newcomb, B. A. 1989. Winter abundance of channel catfish in the channelized Missouri River, Nebraska. North American Journal of Fisheries Management 9: 195-202.

Oliver, J. D., G. F. Holeton, and K. E. Chua. 1979. Overwinter mortality of fingerling smallmouth bass in relation to size, relative energy stores, and environmental temperature. Transactions of the American Fisheries Society 108: 130-136.

Pearson, W. D. and L. A. Krumholz. 1984. Distribution and status of Ohio River fishes. Oak Ridge National Laboratory (Sub-79-7831-1), Oak Ridge, Tennessee.

Raibley, P. T., K. S. Irons, T. M. O’Hara, K. D. Blodgett, and R. E. Sparks. 1997. Winter habitat used by largemouth bass in the Illinois River, a large riverfloodplain ecosystem. North American Journal of Fisheries Management 17: 401-412.

Sheehan, R. J., W. M. Lewis, and L. R. Bodensteiner. 1990. Winter habitat requirements and overwintering of riverine fishes. Final Report, Federal Aid in Sportfish Restoration Program, Project F-79-R.

Sheehan, R. J., and J. L. Rasmussen. 1999. Large rivers. Pgs. 529-559 in Inland fisheries management in North America, $2^{\text {nd }}$ edition. W. A. Hubert and C. C. Kohler, editors. American Fisheries Society, Bethesda, Maryland.

Toneys, M. L., and D. W. Coble. 1979. Size-related, first winter mortality of freshwater fishes. Transactions of the American Fisheries Society 108: 415-419.

Vallazza, J. M., J.W. Deller, W. E. Lynch, and D. L. Johnson. 1994. Seasonal behavior, movements, and habitat preference of hybrid striped bass and sauger in the Ohio River. Final Report. Fish Management in Ohio, Federal Aid in Sport Fish Restoration Project F-69-P. 


\section{Chapter 2. Winter Habitat Use by Fishes in a Large River}

\section{Abstract}

Winter is a critical period during which fishes suffer increased mortality. In order to identify the abiotic conditions large river fish communities use during winter, we electrofished six habitat types in the Belleville Pool, Ohio River. We collected the greatest diversity and abundance of fishes in low-velocity tributary confluences. When water temperatures were $<4^{\circ} \mathrm{C}$, certain species were collected in greater abundance in faster-velocity main channel and back channel habitats. The lack of temperatures $>4{ }^{\circ} \mathrm{C}$ may have left fishes susceptible to current velocity, carrying them out of tributaries into channel habitats. Not all species responded to decreasing water temperatures in the same manner. CCA (canonical correspondence analysis) results showed some species continued to associate with low-velocity tributaries at low temperatures. Species-specific responses to winter conditions may obscure broad generalizations about when and how riverine fishes use overwintering refuges. We recommend that protection and enhancement of tributary habitats can increase the probability of survival of fishes in large rivers during winter.

\section{Introduction}

Physiochemical tolerances of fishes influence range distributions and habitat use. In temperate climates, fishes shift habitats in response to seasonal variations in physiochemical factors. During winter conditions, fishes select refuge habitats where physiochemical factors are unlikely to exceed tolerance limits. In large temperate river systems, extremely low water temperatures during winter coupled with high flows 
increase mortality rates of fishes (Bodensteiner and Lewis 1992; Lyons 1997). Low levels of dissolved oxygen also increase mortality of fishes, and occur typically during ice-cover of backwater areas (Bodensteiner and Lewis 1992; Knights et al. 1995; Johnson et al. 1998).

Many fishes forage infrequently during cold winter extremes, and select refuges that minimize energy depletion (Crawshaw 1984; Carlson 1992). Fishes often increase fat-reserves before winter; hence, reducing mortality associated with energy depletion (Fullerton et al. 2000). However, energy reserves may not suffice given long winters or energy expenditures due to disturbance, such as variation in river flows or boat traffic (Nielsen et al. 1986).

During winter, riverine fishes select habitats with relatively high temperatures and low flows that offer velocity shelters (Logsdon 1993; Bodensteiner and Lewis 1994; Johnson et al. 1998). These conditions have been found in areas other than mainstem river sections, such as off-channel coves, marinas, embayments and industrial warmwater outflows (Sheehan et al. 1994; Gent et al. 1995: Knights et al. 1995; Raibley et al. 1997). Also, backwater areas with relatively warmer temperatures and lower flows provide winter refuge habitats (Bodensteiner and Lewis 1992; Raibley et al. 1997; Sheehan and Rasmussen 1999).

Sheehan et al. (1990) examined temperature and flow requirements in the laboratory for several fishes common in the Ohio River, such as gizzard shad, Dorosoma cepedianum, channel catfish, Ictalurus punctatus, and freshwater drum, Aplodinotus grunniens. These three fishes occupy relatively low velocity areas during winter (Heese and Newcomb 1982; Newcomb 1989; Sheehan et al. 1990; Logsdon 1993; Bodensteiner 
and Lewis 1994). Gizzard shad are vulnerable to winter die-offs during low water temperatures (Miller 1960). Sheehan et al. (1990) also reported temperature preferences of $>4{ }^{\circ} \mathrm{C}$ for many species in large rivers, such as green sunfish, Lepomis cyanellus, bluegill, Lepomis macrochirus, and freshwater drum. Some species, such as channel catfish, black crappie, Pomoxis nigromaculatus, and walleye, Stizostedion vitreum, can maintain swimming abilities at temperatures $<4^{\circ} \mathrm{C}$ (Sheehan et al. 1990). However, temperature, flow preferences, and swimming abilities during low temperatures are unknown for most riverine fishes.

To quantify winter habitats of fishes in large rivers, we sampled the Belleville Pool of the Ohio River during the winter months of 2002 and 2003. Previous research is primarily limited to in vitro analysis of simulated winter abiotic conditions preferred by large river fishes. Our goal was to analyze in situ winter habitat use by fishes in large rivers. Thus, our main objective was to determine abiotic habitat characteristics associated with fish habitat use. We attempted to do this by examining species/habitat associations among main channel, tributary mouth, back channel, head of island, tail of island, and deep hole habitats during winter. Through an understanding of overwintering areas, we hope to provide resource managers with knowledge needed to reduce winter mortality of fishes by protecting and enhancing important habitats.

\section{Methods}

Study site

The Belleville Pool of the Ohio River, created by Belleville Lock and Dam (rkm 328.1), extends upstream to Willow Island Lock and Dam (rkm 260.2). The 67.9 km pool averages $404.5 \mathrm{~m}$ wide, $7.3 \mathrm{~m}$ deep, and comprises 2850 ha of surface area 
(ORSANCO 1994). The deepest section of the pool (15 m) lies directly upstream of Belleville Lock and Dam. A navigation channel (3.7 m deep) is maintained for commercial barge traffic by the United States Army Corps of Engineers (USACE) (ORSANCO 1994). Two other large rivers, the Muskingum River in Ohio, and the Little Kanawha River in West Virginia are navigable tributaries of the Ohio River within the Belleville Pool. The riparian zone is a mixture of hardwood forests, urban and industrial frameworks, and agricultural settings. Most large floodplains near Belleville Pool are heavily urbanized. The two largest population centers along Belleville Pool are Parkersburg, WV (confluence of the Little Kanawha and Ohio rivers) and Marietta, $\mathrm{OH}$ (junction of Muskingum and Ohio rivers).

Habitat classification

For the purpose of defining habitat use by overwintering fishes, we classified six habitat types in the Belleville Pool: main channel, deep hole, back channel, island head, island tail, and tributary confluence (see Vallazza et al. 1994, Cray 1999). Main channel habitats are used as commercial navigation routes, and typically have shallow near-shore areas and deeper mid-channel sections. Deep hole habitats ( $>8 \mathrm{~m}$ in depth) result from dredging or natural scour within main channel or back channel areas. Back channel, island head, and island tail habitats are associated with islands. Back channel habitats are not typically used for commercial navigation and occur between an island and the mainland. The waters immediately adjacent to the upstream and downstream ends of each island are island head and island tail habitats, respectively. Tributary habitats are located, specifically, where the joining waters form a confluence with the mainstem of the Ohio River. 
Habitat selection

To evaluate winter habitat selection by fishes within the Ohio River, we sampled six sites in six habitat categories on six different occasions. Main channel and tributary sites were selected in a constrained random fashion according to their relative abundance in the upper and lower half of the Belleville Pool. We chose six of the seven island habitats located in the Belleville Pool. Island size (measured in length) differed among Blennerhasset (6.4 km), Halfway (1.6 km), Newberry (0.4 km), Marietta (4.8 km), Muskingum (3.2 km), and Neal (2.4 km) Islands, but sample areas within back channel, head, and tail habitats were similar among islands. Depths of main channel and back channel sites ranged from 3 to $8 \mathrm{~m}$, and included near-shore and mid-channel transects. Tributary habitats were 2 to 9 m deep, and included near-shore areas and deeper scour holes. Depths of deep hole habitats ranged from 8 to $14 \mathrm{~m}$, and those of island head and tail habitats ranged from 2 to $6 \mathrm{~m}$.

\section{Data collection}

We sampled fish at the habitat sites during six periods (February 16 - 22, 2002, March 9 - 25, 2002, April 4 - 7, 2002, December 12 - 17, 2002, January 10 -19, 2003, and March 1 -17, 2003). At each site, we sampled fishes with a variable-depth AC electrofishing boat for water depths of 2-15 meters (Grunwald 1983, Newcomb 1989). Three weighted electrodes ( $2 \mathrm{~m}$ sections of 1.25 inch diameter corrugated conduit) were lowered to near the river bottom over a boom connected to the bow. The desired output of the Honda 5 kilowatt 3-phase AC generator, monitored by clip-on gauges, was above 7 Irms, and typically 9-10 Irms while collecting fish. One, two, or three transects were 
electrofished, (depending on the amount of available habitat at a site), in the downstream direction of the river current lasting up to 10-minutes (peddle time) for each transect. During peddle time, the boat (with bow upstream) drifted with the river current. This maintained electrodes near the river bottom, but caused longer transects during higher flows. In habitats with a wide range of depths such as back and main channel habitats, the three transects represented shallow and intermediate depths near each shore and deep areas in mid-channel. Peddle time and number of transects varied with habitat availability at each site. During and after peddle time, fishes were netted from a chase boat or the electrofishing boat. Collected fishes were identified to species, counted, measured (nearest mm total length, TL), and weighed. Large fishes (over $1 \mathrm{~kg}$ ) were weighed to the nearest $25 \mathrm{~g}$ with a Pesola spring scale (5 kg maximum). Smaller fishes (less than $1 \mathrm{~kg}$ ) were weighed to the nearest $1 \mathrm{~g}$ with a Homs spring dial scale $(1 \mathrm{~kg}$ maximum).

Abiotic conditions were measured at each site to further characterize habitat types. After electrofishing at a site, we measured specific conductivity, dissolved oxygen (DO), $\mathrm{pH}$, and temperature at 1-m depth intervals (YSI 6820 meter or Hydrolab Surveyor 4), and estimated surface flow velocity (Marsh-McBirney Flowmate). We estimated turbidity near surface (secchi disk), and at $1 \mathrm{~m}$ depth intervals (YSI 6820 meter) during the second winter sampling (December 2002 to March 2003). We used Tidbit temperature loggers to record water temperature at three back channel and three main channel sites at depths between 1 and $2 \mathrm{~m}$ during both winter samples. 
Statistical analyses

To characterize the six habitat categories, the abiotic variables were averaged by site and sample period. First, the profile values for each abiotic variable, from surface to near bottom were averaged as a single value for each site (except flow and secchi, which were single values). Second, the six site average values for each abiotic variable were averaged as a single value for each habitat type for each of the six periods (e.g., all average temperature values from tributary sites during December 12-17, 2002 were averaged as a single value). Third, the abiotic values from the three sample periods were averaged as a single value for each habitat category for both of the winter samples (February - April, 2002 and December, 2002 - March, 2003). Finally, standard deviations of the averaged abiotic variables were also calculated.

To determine which habitats particular species of fish used at critical low temperatures, we first calculated the proportion of the total catch for each species collected at average temperature values $>4{ }^{\circ} \mathrm{C}, 3<4{ }^{\circ} \mathrm{C}$, and $<3{ }^{\circ} \mathrm{C}$ in each habitat category. These temperature values stem from the laboratory findings of Sheehan et al. (1990) suggesting $<4^{\circ} \mathrm{C}$ is the critical water temperature when many riverine fishes lose their swimming ability and are unable to maintain their position in the water column. Second, we calculated the percentage of the total catch at each temperature range for the five most numerous fishes at each temperature range separately. All other less numerous fishes were calculated as a single group. Lastly, we counted the number of species collected in each habitat category.

We used canonical correspondence analysis (CCA) to explore relationships between species and abiotic variables. Canonical correspondence analysis, a constrained 
ordination approach, allowed concurrent analysis of species abundance, site, and environmental (abiotic) data (ter Braak 1995). A square root transformation of abundance data minimized affects of a few high abundance values (McGarigal et al. 2000). We conducted CCAs with data from each winter sample separately using an Excel macro (Eric Smith, Virginia Polytechnic Institute and State University). A significant high water event during March 2003 (see Figure 2b) interrupted our data collection and forced us to finish over a much greater length of time than the previous two sample periods. For this reason, the CCA for the second winter sample only represents data collected from December 12, 2002 through January 19, 2003. Results

Tributary habitats represented important overwintering habitats for large river fishes. Tributary habitats consistently had the lowest average flow velocity (mode of 0.1 $\mathrm{m} / \mathrm{s}$ ) during all sample periods (Table 1). Low flow velocities likely contributed to the relatively high numbers of fishes caught at tributaries. Fifty-eight percent of the total individuals collected during both winter samples were from tributaries. More individuals were collected in tributaries during the warmer first winter sample ( $87 \%$ of the total individuals from this sample) than the colder second winter sample (Table 1). Thirtynine percent of the total individuals from the second winter sample were collected in tributaries.

Species presence and abundance in both back and main channel habitats increased during colder water temperatures. Forty-three percent and $14 \%$ of all individuals were collected in main channel and back channel habitats, respectively, during the colder winter sample. When sites had an average temperature $>4{ }^{\circ} \mathrm{C}$, more individuals were 
collected in tributaries (66 \%) than main and back channel sites (30 \%) (Figure 1a). At temperatures between 3 and $4{ }^{\circ} \mathrm{C}$, more individuals were still collected at tributaries, but at a reduced proportion compared to main and back channel sites at temperatures $>4{ }^{\circ} \mathrm{C}$ (Figure 1b). A shift to a greater proportion of individuals occupying main and back channel sites occurred when water temperatures at all habitat types were $<3^{\circ} \mathrm{C}$ (Figure 1c). Sixty-six percent of the individuals were collected at main channel sites, while $31 \%$ were collected at tributary sites at water temperatures $<3{ }^{\circ} \mathrm{C}$.

Freshwater drum was the most abundant species captured, representing $48 \%$ of the total catch from both winter samples. During the warmer first winter, $90 \%$ of the freshwater drum individuals were collected from tributaries. Freshwater drum dominated the pattern of shifting from tributary to main channel habitats when water temperatures at all habitat types were $<3{ }^{\circ} \mathrm{C}$ (Figure 1). During the colder sample, $37 \%$ of the freshwater drum individuals were collected from tributaries, while 50\% were collected in main channel sites. Other less numerous species followed a similar pattern.

Channel catfish, the second most abundant species, represented $21 \%$ of the total catch from both winter samples. Sixty-three percent of the channel catfish individuals were collected from tributary habitats during the warmer sample. Channel catfish followed a similar yet more pronounced pattern as freshwater drum by shifting to main and back channel habitats when water temperatures at all habitat types were $<4{ }^{\circ} \mathrm{C}$ (Figure 1). Fifty-three percent of the channel catfish individuals were collected in tributaries and $43 \%$ in main and back channel habitats at temperatures $>4{ }^{\circ} \mathrm{C}$. At temperatures between 3 and $4{ }^{\circ} \mathrm{C}, 84 \%$ of the channel catfish individuals were collected 
in main and back channel habitats. Likewise, $83 \%$ of all channel catfish individuals were collected in main and back channel sites when temperatures were $<3^{\circ} \mathrm{C}$.

Tributary habitats also had the highest species diversity of all habitat types. A total of 19 species were collected in tributaries, while totals of 14 and 11 species were collected in main channel and back channel habitats, respectively (Figure 3). Even during January 10 -19, 2003, the coldest sampling period (average water temperatures ranged between 2.1 and $3.0^{\circ} \mathrm{C}$; Table 1), tributaries still contained the highest species diversity ( $\mathrm{N}=13$ ). However, most of the species collected in January 2003 were from one site, Bull Creek.

High abundance and species diversity occurred in Bull Creek (a tributary habitat) during both winter samples. During the second winter sample, $75 \%$ of the fish captured in tributaries and $30 \%$ of the total catch from all habitat types were from Bull Creek. Bull Creek had the single greatest total catch of fishes at one site (134 individuals on January 11,2003 ) when the water temperature was $3.2^{\circ} \mathrm{C}$ (Figure 5 shows a captured sonar image of this event). Interestingly, immediately downstream from Bull Creek, the largest single catch of fishes at a main channel site occurred on the same day.

The CCA results indicate which abiotic conditions correspond with individual species habitat use. The large difference between mean abiotic conditions of the two winter samples, (February 7, 2002 - April 7, 2002 had warmer water temperatures than December 12, 2002 - March 17, 2003; Figure 2 and Table 1), offered a chance to explore individual species differences in habitat use during winter. Because one fish species (freshwater drum) dominated our collections, these exploratory results allowed us to see if other species followed similar patterns of winter habitat use as freshwater drum. 
Freshwater drum (\# 23 in Figure 4a) corresponded with decreasing flow values and tributary sites during the warmer winter sample. Channel catfish (\# 13 in Figure 4a) were weakly linked to increasing water temperatures and the sites that contained them (4 main channel sites and 1 tributary site, Duck Creek on March 24, 2002, when 50 of the 100 fishes collected were channel catfish) during the warmer sample. Only channel catfish weakly correlated with water temperatures during the warmer period, probably due to increased average water temperatures across all habitat types during this time period (Table 1). During the first winter sample, gizzard shad (\# 2 in Figure 4a) closely associated with increased conductivity values of some tributary sites. The other species collected during the first sample period corresponded with relatively lower flows and slightly increasing depths. Most of these fishes ( 9 of the 13 species), however, were collected in negligible abundance from two tributary sites, Bull and Duck Creeks.

Contrary to the warmer sampling period, freshwater drum (\# 23 in Figure 4b) corresponded equally (but to a slightly lesser intensity) with channel catfish (\# 13 in Figure 4b) to increasing flow velocity, water temperature, and conductivity during the colder sampling period. Mooneye, Hiodon tergisus, (\#3 in Figure 4b) also closely coincided with increasing values of these same abiotic variables. Main and back channel sites were associated with increasing flow velocity, temperature and conductivity axes. Fourteen of the 20 species were correlated with decreasing values of these three major axes and were associated with tributary sites.

\section{Discussion}

Low-velocity tributary habitats contained the highest abundances and diversity of fishes during February 2002 - March 2003 sample sessions. Although other unmeasured 
variables may explain fish use of tributary habitats during winter, we believe that low velocity is an important abiotic regulator of winter habitat use. Supporting this conclusion, largemouth bass, Micropterus salmoides, in the Hudson River (Carlson 1992), and river carpsucker, Carpiodes carpio, and sauger, Stizostedion canadense, in the Missouri River (Braaten and Guy 1999) also used tributary confluences during winter. We do not believe that electrofishing sampling efficiency was higher in tributary habitats because ambient conductivities (Reynolds 1996) were similar in all habitats during both years (ranged from $182-303 \mathrm{uS} / \mathrm{cm}$ ) and were close to the standard conductivity of a fish (115 uS/cm) (Miranda and Dolan 2003).

River current velocities may overcome fishes' swimming ability to hold their position in preferred habitats such as tributaries as water temperatures decline below 4 ${ }^{\circ} \mathrm{C}$. During our coldest sample periods (water temperatures $<4{ }^{\circ} \mathrm{C}$ ), the catch of several species increased in back channel or main channel habitats, including channel catfish, and freshwater drum (Figure 1). We did not have high catches of fish in back and main channel habitats, except when average water temperatures in low-velocity tributary habitats were $<3{ }^{\circ} \mathrm{C}$. On January 11,2003 , all tributary habitats were $<3{ }^{\circ} \mathrm{C}$, except for Bull Creek $\left(3.2^{\circ} \mathrm{C}\right)$ when the single highest total catch of fishes occurred (Figure 5). It is possible that previous to this sampling date, the high flow conditions and declining water temperatures (Figure 2b) forced fishes to occupy relatively lower-velocity tributary sites like Bull Creek. On January 11, 2003, the declining temperatures may have limited fishes’ swimming ability. The minimum amount of flow that existed in Bull Creek on that day may have swept fishes downstream into an eddy current along the main channel shoreline immediately below the mouth of Bull Creek, where they were collected. In the 
upper Mississippi River, Bodensteiner and Lewis (1994) documented increased flow velocity coupled with near-freezing water temperature caused freshwater drum to lose equilibrium and become incapacitated, resulting in large numbers of individuals floating downstream with the current.

The lack of sufficiently warmer temperatures may force fishes to occupy main and back channel habitats. Average water temperatures in channel habitats were higher than tributaries during January 2003, yet still below the critical $4{ }^{\circ} \mathrm{C}$ (Table 1). Sheehan et al. (1990) reported riverine fishes in laboratory conditions preferred water temperatures $>4{ }^{\circ} \mathrm{C}$. If water temperatures $>4{ }^{\circ} \mathrm{C}$ are unavailable, current velocities may overwhelm fishes’ swimming ability, sending them downstream where they collect in channel borders. However, the ability to withstand critically low water temperatures may vary between species.

Species-specific responses to winter conditions result in differential habitat use. Physiochemical tolerances vary among fish species (Sheehan et al. 1990), which was evident between our two most abundant species. For example, channel catfish occupied warmer and deeper habitats, while freshwater drum occupied shallower habitats with lower flow velocities during February 16 through April 7, 2002 (Figure 4a). During this time period, freshwater drum appeared less tolerant of higher flow velocities, but used shallower habitats than channel catfish. However, during the coldest months of 2003, freshwater drum occupied warmer and deeper habitats with higher flow velocities, similar to channel catfish (Figure 4b), suggesting a mutual tolerance of physiochemical factors during severe winter conditions. Conversely, other species continued to associate with lower temperatures at low-velocity tributaries (Figure 4b). 
Our study was conditional on six habitats, but other overwintering habitats occur in Belleville Pool. We also sampled and found high diversity and abundance of fishes in an embayment, downstream of a wing dam, and within an industrial warm-water outflow, but these habitats (uncommon within Belleville Pool) were not part of our study design. Off-channel coves, marinas, embayments and industrial warm-water outflows have been shown to be valuable overwintering refuges for fishes (Sheehan et al. 1994; Gent et al. 1995; Knights et al. 1995; Raibley et al. 1997). Additional studies of alternative habitats, such as embayments, warm-water outflows, artificial structures, and tailwaters, are needed to further address fish-habitat relationships in large rivers.

In conclusion, our data support tributary confluences as important overwintering sites for fishes in the Belleville Pool, Ohio River. Some fishes, however, shift to main and back channel habitats when temperatures are $<3{ }^{\circ} \mathrm{C}$. If altered or unprotected, the loss of overwintering habitats at tributary mouths could contribute to increased mortality of fishes during winter. Additionally, tributary mouths are susceptible to disturbance from boat and barge traffic, and fishes using these habitats during winter could be displaced. Nielsen (1986) and Sheehan and Rasmussen (1999) suggested detrimental effects of commercial boat traffic on fishes in large rivers. Passage of boats during winter causes turbulence, possibly forcing fish from their overwintering position. Those fishes forced into less suitable conditions may suffer increased mortality. Protecting tributary confluences from further degradation by commercial boat traffic, pollution, sedimentation, and channelization, among others, may increase the probability of survival of fishes in large rivers. 


\section{Literature Cited}

Bodensteiner, L. R., and W. M. Lewis. 1992. Role of temperature, dissolved oxygen, and backwaters in the winter survival of freshwater drum (Aplodinotus grunniens) in the Mississippi River. Canadian Journal of Fisheries and Aquatic Sciences 49: 173-184.

Bodensteiner, L. R., and W. M. Lewis. 1994. Downstream drift of fishes in the upper Mississippi River during winter. Journal of Freshwater Ecology 9: 45-56.

Braaten, P. J., and C. S. Guy. 1999. Relations between physicochemical factors and abundance of fishes in tributary confluences of the lower channelized Missouri River. Transactions of the American Fisheries Society 128: 1213-1221.

Carlson, D. M. 1992. Importance of wintering refugia to the largemouth bass fishery in the Hudson River estuary. Journal of Freshwater Ecology 7(2): 173-180.

Crawshaw, L. I. 1984. Low temperature dormancy in fish. American Journal of Physiology 246: 479-486.

Cray, D. C. 1999. The influence of geomorphology on fish assemblages of Ohio River embayments. M.S. Thesis. The Ohio State University, Columbus, Ohio.

Fullerton, A. H., J. E. Garvey, R. A. Wright, and R. A. Stein. 2000. Overwinter growth and survival of largemouth bass: interactions among size, food, origin, and winter severity. Transactions of the American Fisheries Society 129: 1-12.

Gent, R., J. Pitlo, Jr., and T. Boland. 1995. Largemouth bass response to habitat and water quality rehabilitation in a backwater of the upper Mississippi River. North American Journal of Fisheries Management 15: 784-793.

Grunwald, G. L. 1983. Modification of alternating current electrofishing gear for deep water sampling. Pgs. 177-187 in Proceedings of the 39th Annual Upper Mississippi River Conservation Meeting, 16-18 March, Quincy, Illinois.

Heese, L. W., and B. A. Newcomb. 1982. On estimating the abundance of fish in the upper channelized Missouri River. North American Journal of Fisheries Management 2: 80-83. 
Johnson, B. L., B. C. Knights, J. W. Barko, R. F. Gaugush, D. M. Soballe, and W. F. James. 1998. Estimating flow rates to optimize winter habitat for centrarchid fish in Mississippi River (USA) backwaters. Regulated Rivers Research and Management 14: 499-510.

Knights, B. C., D. L. Johnson, and M. H. Sandheinrich. 1995. Responses of bluegills and black crappie to dissolved oxygen, temperature, and current in backwater lakes of the Upper Mississippi River during winter. North American Journal of Fisheries Management 15: 390-399.

Logsdon, D. E. 1993. Suitability of side channel border and wing dam habitats for fishes overwintering in Pool 26 of the Mississippi River. M.S. Thesis, Department of Zoology, Southern Illinois University, Carbondale, Illinois.

Lyons, J. 1997. Influence of winter starvation on the distribution of smallmouth bass among Wisconsin streams: a bioenergetics modeling assessment. Transactions of the American Fisheries Society 126: 157-162.

McGarigal, K., S. Cushman, and S. Stafford. 2000. Multivariate statistics for wildlife and ecology research. Springer-Verlag, New York.

Miller, R. R. 1960. Systematics and biology of the gizzard shad (Dorosoma cepedianum) and related fishes. Fishery Bulletin 60: 371-392.

Miranda, L. E., and C. R. Dolan. 2003. Test of a power transfer model for standardized electrofishing. Transactions of the American Fisheries Society 132: 1179-1185.

Nielsen, L. A., R. J. Sheehan, and D. J. Orth. 1986. Impacts of navigation on riverine fish production in the United States. Polish Archives of Hydrobiology 33: 277294.

Newcomb, B. A. 1989. Winter abundance of channel catfish in the channelized Missouri River, Nebraska. North American Journal of Fisheries Management 9: 195-202.

Pearson, W. D., and L. A. Krumholz. 1984. Distribution and status of Ohio River fishes. Oak Ridge National Laboratory (Sub-79-7831-1), Oak Ridge, Tennessee.

ORSANCO (Ohio River Valley Water Sanitation Commission). 1994. Ohio River Water Quality Fact Book, Ohio River Valley Water Sanitation Commission. Cincinnati, Ohio. 
Raibley, P. T., K. S. Irons, T. M. O’Hara, K. D. Blodgett, and R. E. Sparks. 1997. Winter habitat used by largemouth bass in the Illinois River, a large riverfloodplain ecosystem. North American Journal of Fisheries Management 17: 401-412.

Reynolds, J. B. 1996. Electrofishing. Pgs. 221-223 in Fisheries techniques. B. R. Murphy and D. W. Willis, editors. American Fisheries Society, Bethesda, Maryland.

Sheehan, R. J., W. M. Lewis, and L. R. Bodensteiner. 1990. Winter habitat requirements and overwintering of riverine fishes. Final Report, Federal Aid in Sportfish Restoration Program, Project F-79-R.

Sheehan, R. J., W. M. Lewis, and L. R. Bodensteiner. 1994. Winter habitat requirements and overwintering of riverine fishes. Fisheries Research Laboratory, S. Illinois University, Carbondale, Illinois. Final Performance Report F-79-R-6.

Sheehan, R. J., and J. L. Rasmussen. 1999. Large rivers. Pgs. 529-559 in Inland fisheries management in North America, $2^{\text {nd }}$ edition. W. A. Hubert and C. C. Kohler, editors. American Fisheries Society, Bethesda, Maryland.

ter Braak, C. J. F. 1995. Ordination. Pgs. 91-173 in Data analysis in community and landscape ecology. R. H. G. Jongman, C. J. F. ter Braak, and O. F. R. van Tongeren, editors. Cambridge University Press, Cambridge, United Kingdom.

Vallazza, J. M., J.W. Deller, W. E. Lynch, and D. L. Johnson. 1994. Seasonal behavior, movements, and habitat preference of hybrid striped bass and sauger in the Ohio River. Final Report. Fish Management in Ohio, Federal Aid in Sport Fish Restoration Project F-69-P.

Wright, R. A., J. E. Garvey, A. H. Fullerton, and R. A. Stein. 1999. Predicting how winter affects energetics of age-0 largemouth bass: how do current models fare? Transactions of the American Fisheries Society 128: 603-612. 
Figure 1. The proportion of the total catch of each species among habitat categories.

Data are separated by water temperatures $>4{ }^{\circ} \mathrm{C}(\mathrm{A}), 3<4{ }^{\circ} \mathrm{C}(\mathrm{B})$, and $<3{ }^{\circ} \mathrm{C}(\mathrm{C})$ within the Belleville Pool, Ohio River, during February 17 through April 7, 2002 and December 12, 2002 through March 17, 2003. Sites are abbreviated as bc (back channel), dh (deep hole), ih (island head), it (island tail), mc (main channel), and tr (tributary). Fish species are abbreviated as D. cepedianum (gizzard shad), H. tergisus (mooneye), $M$. storeriana (silver chub), C. carpio (river carpsucker), I. bubalus (smallmouth buffalo), I. punctatus (channel catfish), M. chrysops (white bass), M. saxatilis x chrysops (hybrid striped bass), and A. grunniens (freshwater drum).

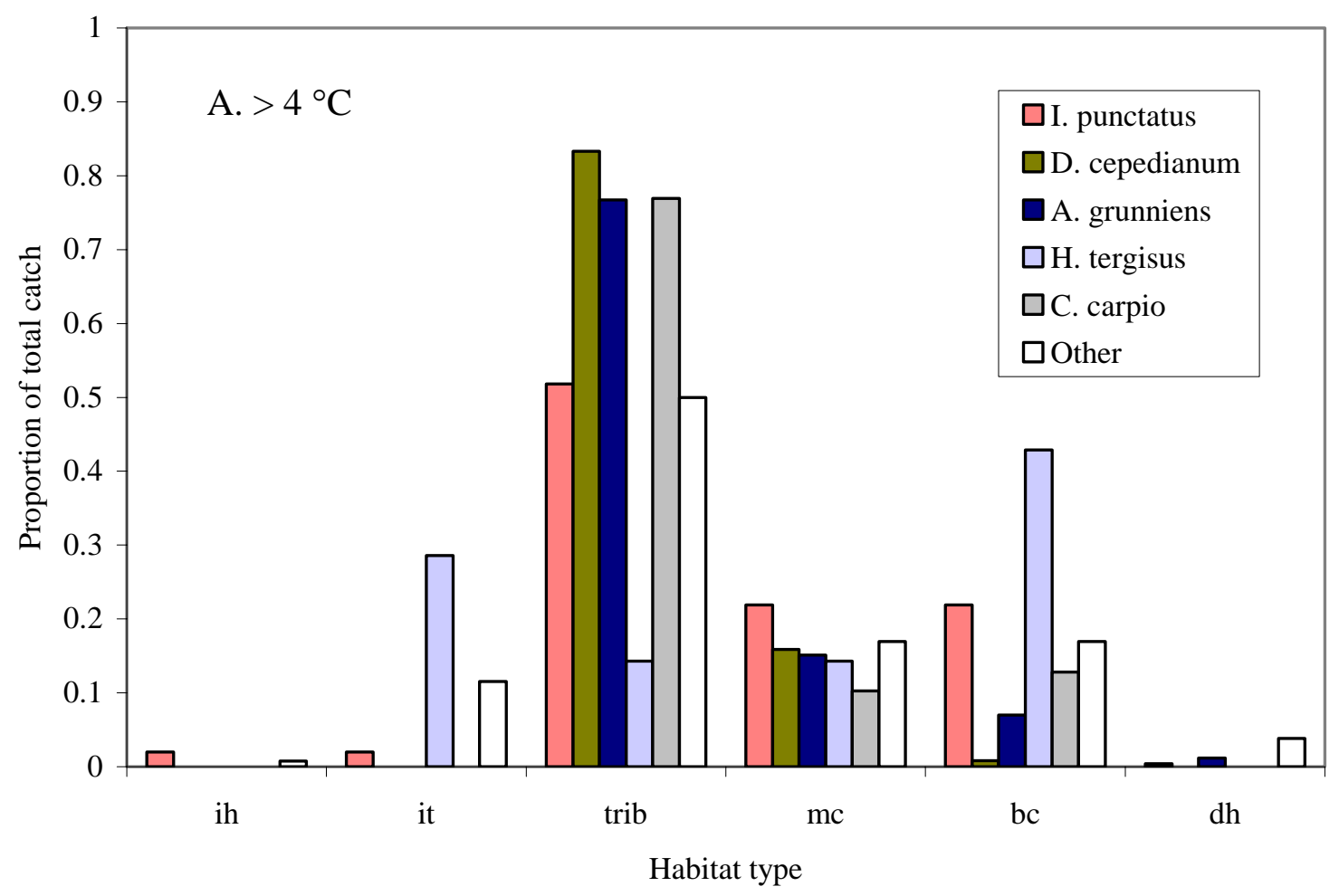



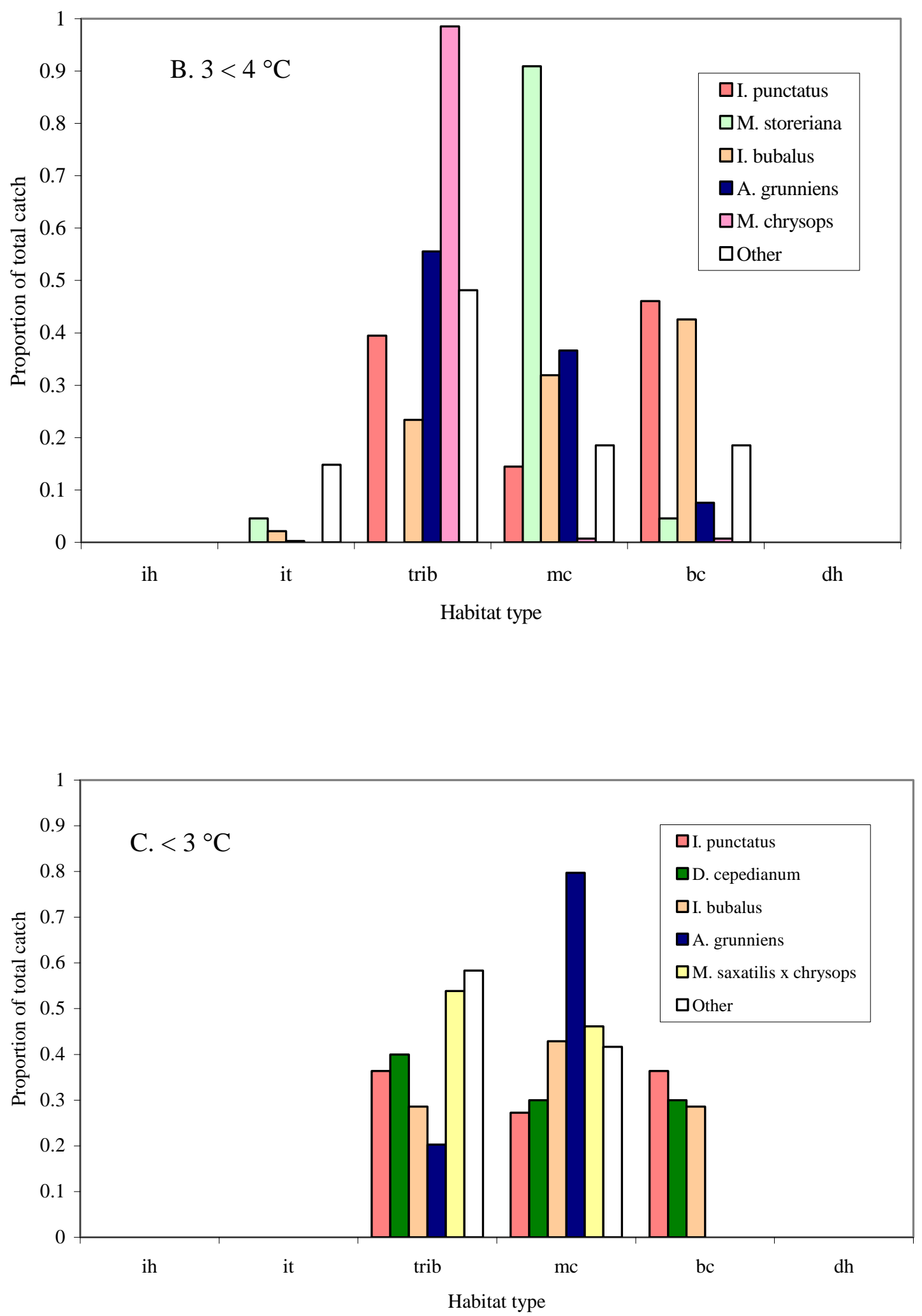
Figure 2. Water temperature (broken line), stage height (solid line), and sampling session dates (x) in Belleville Pool, Ohio River, during December 1, 2001 through April 14, 2002 (A) and December 1, 2002 through April 14, 2003 (B).

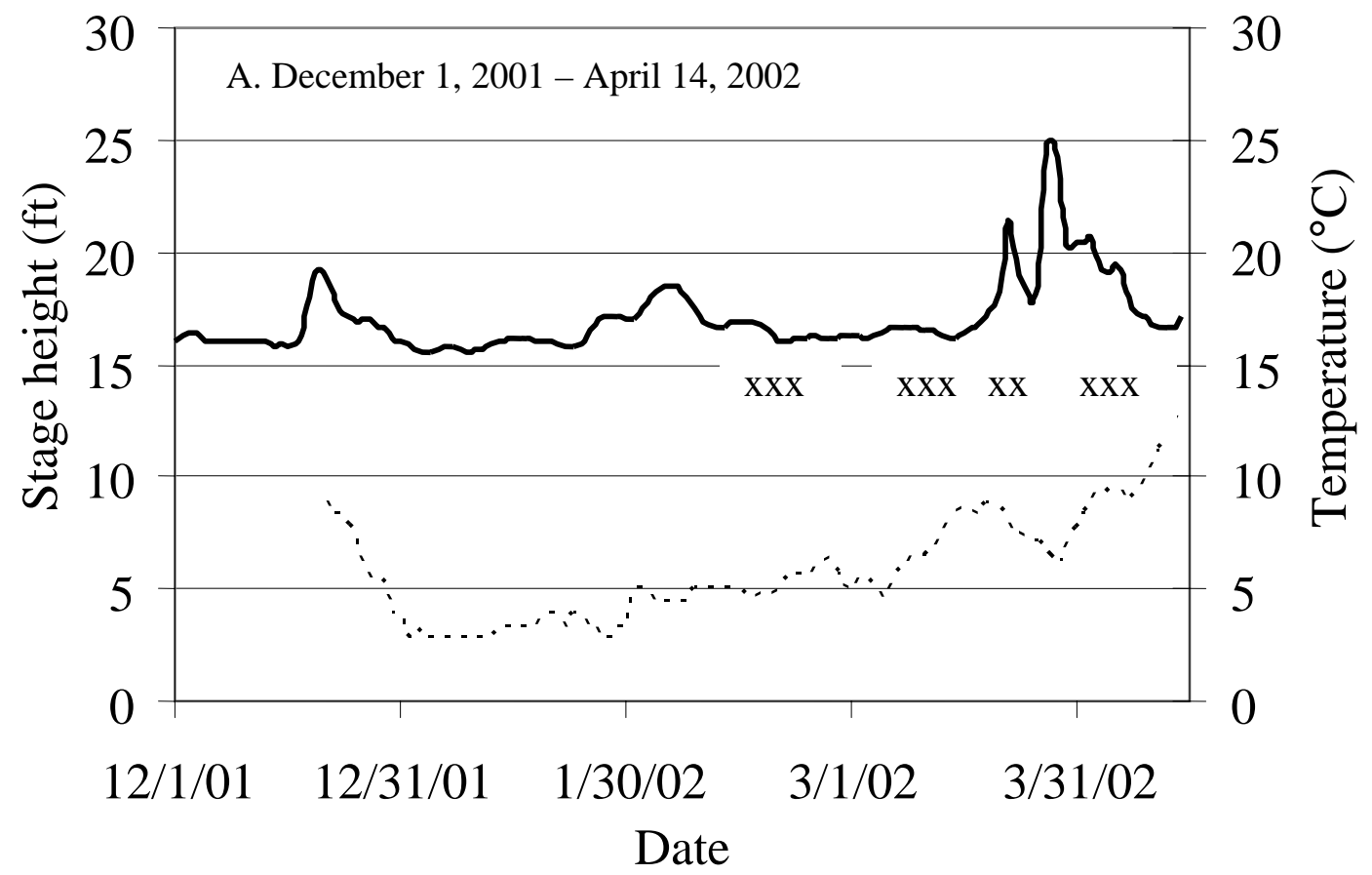




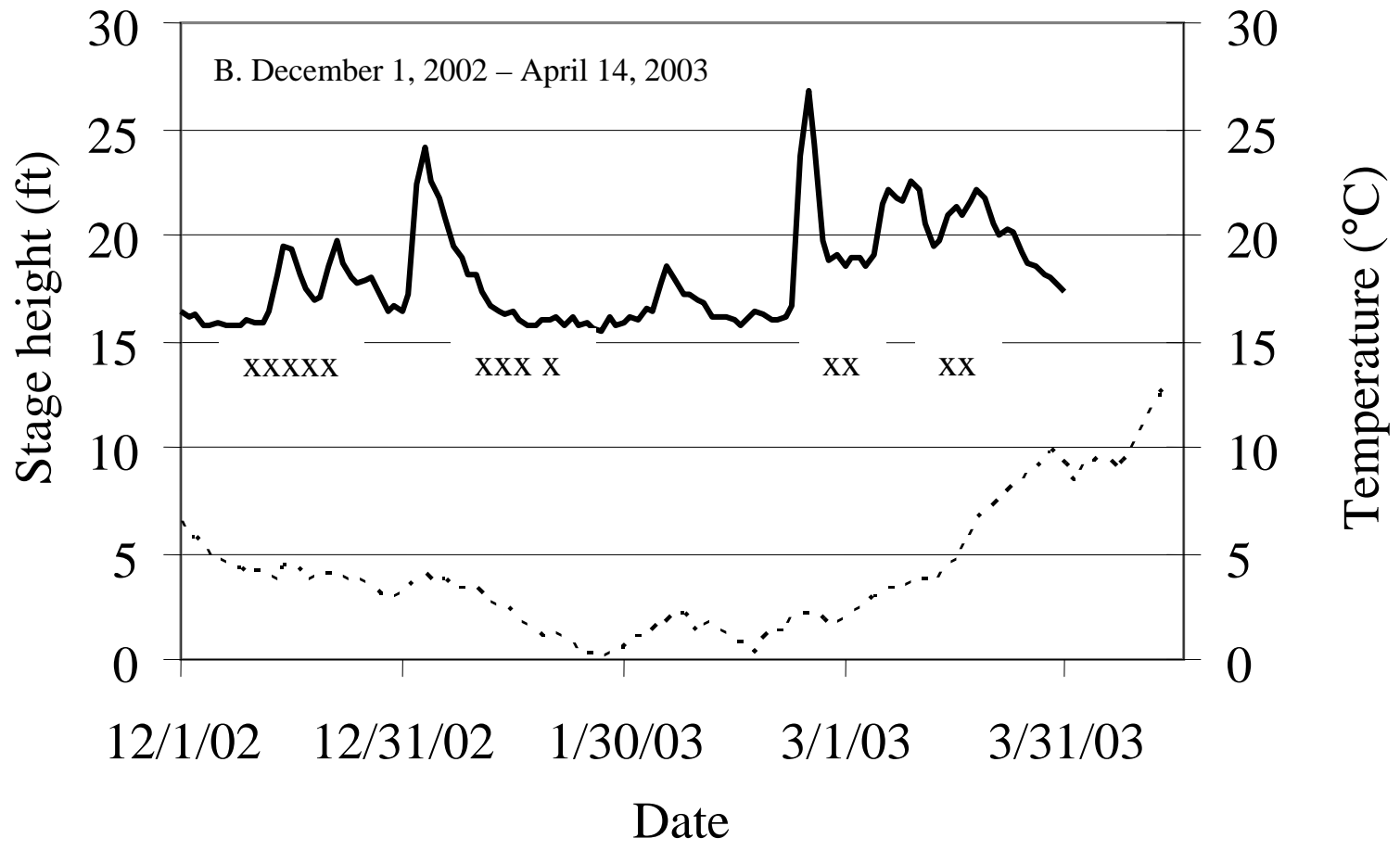


Figure 3. The number of species in each habitat category collected in the Belleville Pool during December 1, 2001 through April 14, 2002 and December 1, 2002 through April 14, 2003. Sites are abbreviated as ih (island head), it (island tail), trib (tributary), mc (main channel), bc (back channel), and dh (deep hole).

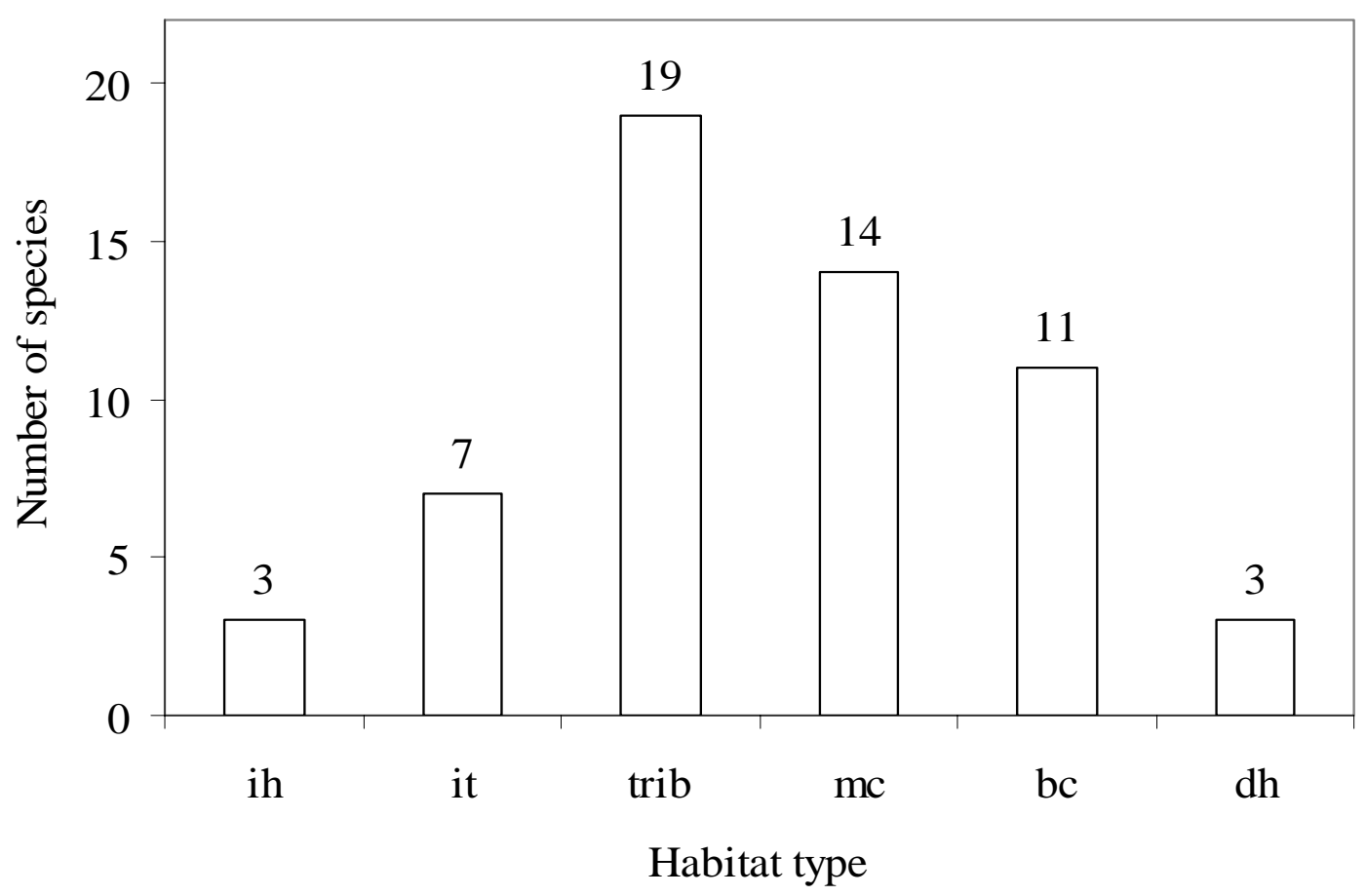


Figure 4. Triplot from canonical correspondence analysis (CCA) of species abundance, sites, and abiotic variables from February 16, 2002 through April 7, 2002 (A) and December 12, 2002 through January 19, 2003 (B) in the Belleville Pool, Ohio River. Sites are symbolized as $\diamond$ (tributary), + (island head), ○ (island tail), $\square$ (back channel), $\Delta$ (main channel), and $\mathrm{x}$ (deep hole). Abiotic variables are depth, specific conductivity (Cond), temperature (Temp), turbidity (Turb), and water velocity (Flow). Species are numbered as 1) I. bdellium, 2) D. cepedianum, 3) H. tergisus, 4) Cyprinus carpio, 5) M. storeriana, 6) N. atherinoides, 7) Carpiodes carpio, 8) C. cyprinus, 9) C. velifer, 10) M. erythrurum, 11) M. macrolepidotum, 12) I. bubalus, 13) I. punctatus, 14) P. olivaris, 15) M. chrysops, 16) M. chrysops x saxatilis, 17) A. rupestris, 18) P. nigromaculatus, 19) M. punctatus, 20) L. macrochirus, 21) S. canadense, 22) S. vitreum, and 23) A. grunniens. 
A. February 16, 2002 - April 7, 2002

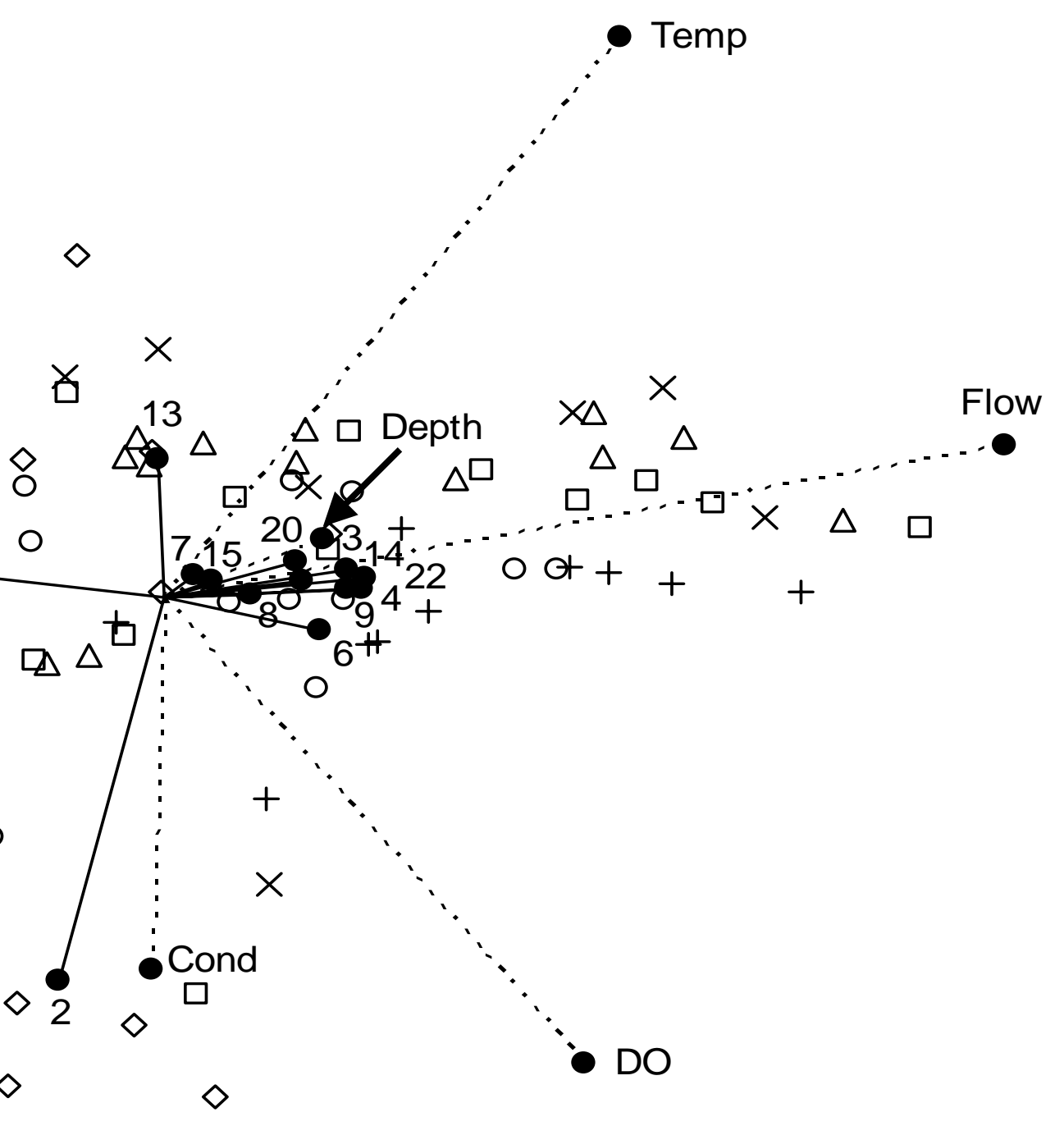

Legend

$\diamond$ Tributary

$\triangle$ Main Channel

$\square$ Back Channel

- Island Tail

+ Island Head

x Deep Hole 


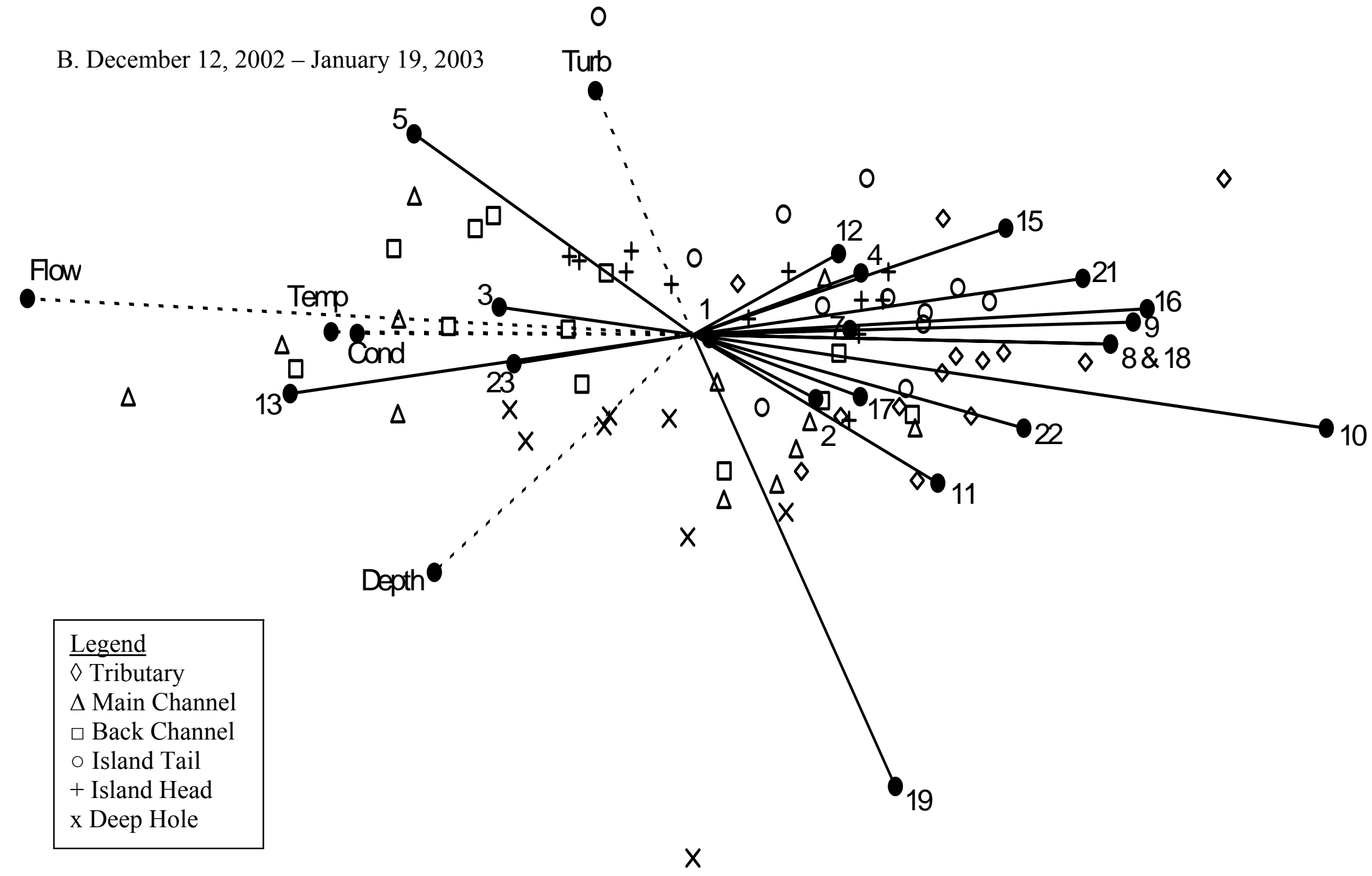


Figure 5. The captured sonar image from Bull Creek on January 11, 2003, when the single highest total catch of fishes occurred. Black streak like blotches are individual fish.

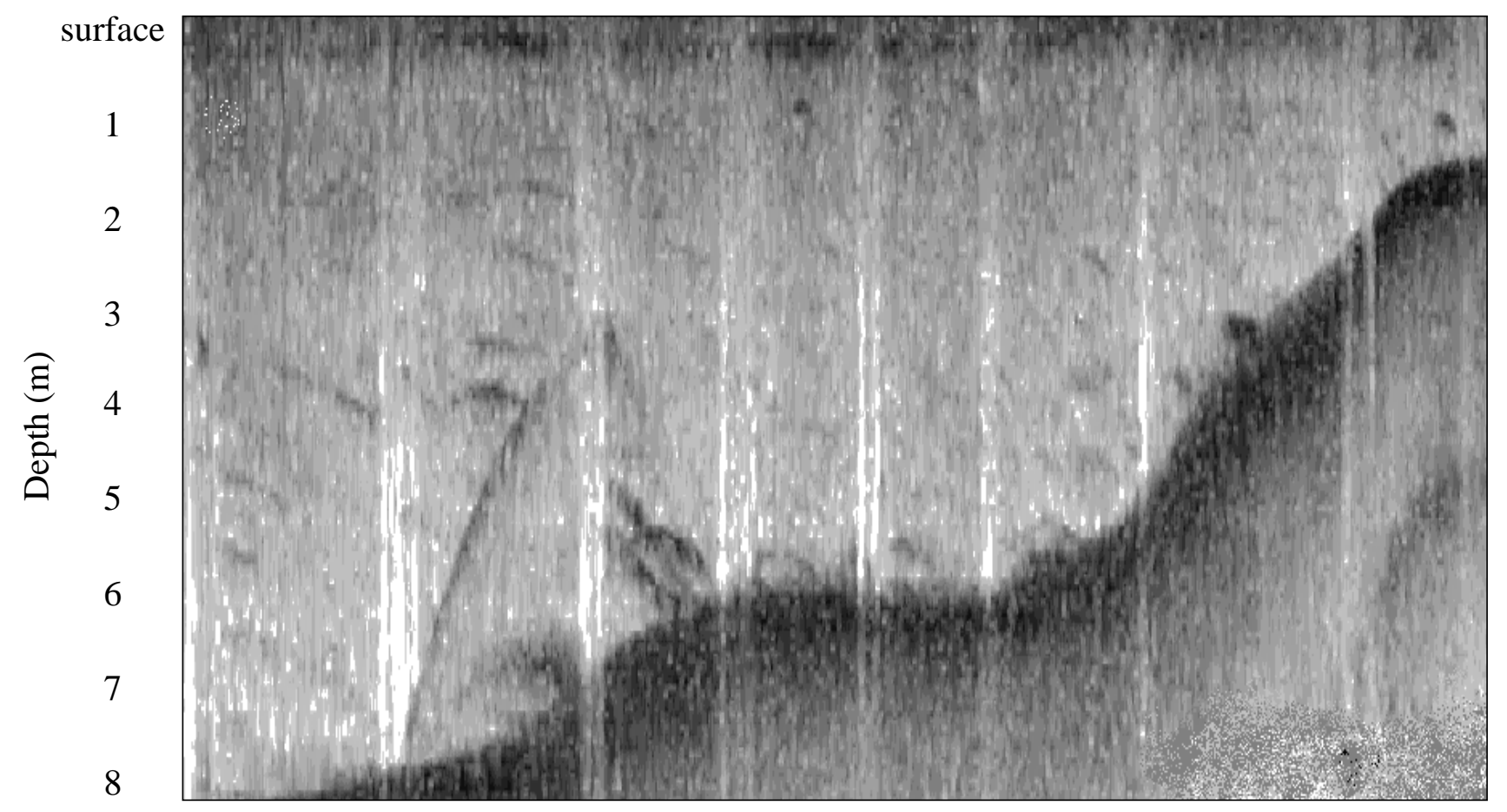


Table 1. Average abiotic conditions of all sites in six habitat types during six different sampling periods between February 16 through April 7, 2002 and December 12, 2002 through March 17, 2003 in the Belleville Pool, Ohio River. Standard deviations are in parentheses. Habitat types and abiotic variables with no values were not sampled during February 16 - 22, 2002 and the deep hole category with no standard deviation values only had one sample site during this period. 
Habitat types

\begin{tabular}{|c|c|c|c|c|c|c|}
\hline Date & $\begin{array}{l}\text { Island } \\
\text { Head }\end{array}$ & $\begin{array}{c}\text { Island } \\
\text { Tail }\end{array}$ & $\begin{array}{c}\text { Back } \\
\text { channel }\end{array}$ & $\begin{array}{c}\text { Main } \\
\text { channel }\end{array}$ & Tributary & $\begin{array}{c}\text { Deep } \\
\text { hole }\end{array}$ \\
\hline \multicolumn{7}{|l|}{ February 16 - 22, 2002} \\
\hline Temp. $\left({ }^{\circ} \mathrm{C}\right)$ & & & & & $4.8(0.35)$ & $5.4(-)$ \\
\hline D. O. (mg/L) & & & & & $13.3(0.25)$ & $13.6(-)$ \\
\hline Flow (m/s) & & & & & $0.1(0.02)$ & \\
\hline Spec. Cond. (uS/cm) & & & & & $390.1(87.1)$ & $373.0(-)$ \\
\hline \multicolumn{7}{|l|}{ March 9 - 25, 2002} \\
\hline Temp. $\left({ }^{\circ} \mathrm{C}\right)$ & $7.7(0.54)$ & $7.1(0.60)$ & $6.9(1.22)$ & $7.3(0.07)$ & $6.8(0.74)$ & $7.3(0.03)$ \\
\hline D. O. (mg/L) & $8.3(0.49)$ & $8.3(0.53)$ & $8.4(0.58)$ & $8.5(0.46)$ & $8.1(0.49)$ & $8.5(0.52)$ \\
\hline Flow $(\mathrm{m} / \mathrm{s})$ & $0.5(0.30)$ & $0.3(0.20)$ & $0.4(0.29)$ & $0.4(0.17)$ & $0.1(0.13)$ & $0.4(0.06)$ \\
\hline Spec. Cond. (uS/cm) & $353.3(46.7)$ & $354.6(45.0)$ & $355.6(40.5)$ & 338.7 (47.1) & 316.2 (48.1) & $337.9(53.6)$ \\
\hline \multicolumn{7}{|l|}{ April 4 - 7, 2002} \\
\hline Temp. $\left({ }^{\circ} \mathrm{C}\right)$ & $9.0(0.28)$ & $9.0(0.30)$ & $9.0(0.37)$ & $8.9(0.20)$ & $9.4(0.73)$ & $8.9(0.09)$ \\
\hline D. O. (mg/L) & $10.7(0.67)$ & $10.5(0.26)$ & $10.5(0.26)$ & $10.8(0.85)$ & $9.5(1.64)$ & $11.0(1.12)$ \\
\hline Flow $(\mathrm{m} / \mathrm{s})$ & $0.6(0.24)$ & $0.4(0.22)$ & $0.7(0.23)$ & $0.7(0.24)$ & $0.2(0.22)$ & $1.0(0.15)$ \\
\hline Spec. Cond. (uS/cm) & $265.9(47.4)$ & $267.0(46.5)$ & $267.4(50.7)$ & $261.9(38.2)$ & $282.2(103.7)$ & $250.9(7.00)$ \\
\hline \multicolumn{7}{|l|}{ February 16 - April 7, 2002} \\
\hline Temp. $\left({ }^{\circ} \mathrm{C}\right)$ & $8.4(0.80)$ & $8.1(1.07)$ & $6.9(1.39)$ & $8.3(0.84)$ & $7.5(2.25)$ & $7.7(1.31)$ \\
\hline D. O. (mg/L) & $9.6(1.38)$ & 9.5 (1.19) & $9.4(1.13)$ & $9.9(1.37)$ & $10.0(2.24)$ & $10.3(2.06)$ \\
\hline Flow $(\mathrm{m} / \mathrm{s})$ & $0.6(0.27)$ & $0.4(0.21)$ & $0.5(0.30)$ & $0.6(0.28)$ & $0.1(0.17)$ & $0.7(0.35)$ \\
\hline Spec. Cond. (uS/cm) & $306.2(64.0)$ & $307.4(63.2)$ & 311.5 (63.8) & $292.6(56.1)$ & $319.3(92.0)$ & $305.6(61.2)$ \\
\hline
\end{tabular}




\begin{tabular}{|c|c|c|c|c|c|c|}
\hline Date & $\begin{array}{l}\text { Island } \\
\text { Head }\end{array}$ & $\begin{array}{l}\text { Island } \\
\text { Tail }\end{array}$ & $\begin{array}{c}\text { Back } \\
\text { channel }\end{array}$ & $\begin{array}{c}\text { Main } \\
\text { channel }\end{array}$ & Tributary & $\begin{array}{l}\text { Deep } \\
\text { hole }\end{array}$ \\
\hline \multicolumn{7}{|l|}{ December 12 - 17, 2002} \\
\hline Temp. $\left({ }^{\circ} \mathrm{C}\right)$ & $4.0(0.55)$ & $4.2(0.56)$ & $4.1(0.52)$ & $4.0(0.47)$ & $4.1(0.74)$ & $4.2(0.42)$ \\
\hline D. O. (mg/L) & $7.3(0.14)$ & $8.5(1.09)$ & $7.9(0.67)$ & $7.2(0.11)$ & $7.1(0.58)$ & $8.4(0.00)$ \\
\hline Flow (m/s) & $0.6(0.29)$ & $0.2(0.10)$ & $0.7(0.21)$ & $0.5(0.26)$ & $0.1(0.13)$ & $0.5(0.15)$ \\
\hline Spec. Cond. (uS/cm) & $424.5(80.6)$ & $434.2(76.3)$ & $423.5(91.7)$ & $460.3(60.5)$ & 336.5 (95.3) & $405.3(61.0)$ \\
\hline \multicolumn{7}{|l|}{ January 10 -19, 2003} \\
\hline Temp. $\left({ }^{\circ} \mathrm{C}\right)$ & $2.3(1.10)$ & 2.7 (1.07) & $2.5(1.29)$ & $2.5(0.97)$ & $2.1(1.05)$ & $3.0(0.73)$ \\
\hline D. O. (mg/L) & $13.4(0.17)$ & $13.3(0.60)$ & $13.4(0.23)$ & $13.4(0.67)$ & $13.7(0.33)$ & $13.5(0.49)$ \\
\hline Flow $(\mathrm{m} / \mathrm{s})$ & $0.4(0.20)$ & $0.1(0.08)$ & $0.4(0.25)$ & $0.4(0.28)$ & $0.1(0.08)$ & $0.6(0.23)$ \\
\hline Spec. Cond. (uS/cm) & $443.0(41.0)$ & $434.2(41.5)$ & $446.8(51.0)$ & $428.4(32.6)$ & $417.9(54.0)$ & $404.6(13.2)$ \\
\hline \multicolumn{7}{|l|}{ March 1 -17, 2003} \\
\hline Temp. $\left({ }^{\circ} \mathrm{C}\right)$ & $4.1(1.47)$ & $4.1(1.44)$ & 4.1 (1.39) & $3.8(1.31)$ & $4.1(1.96)$ & $2.7(1.03)$ \\
\hline D. O. (mg/L) & $13.2(0.35)$ & $13.0(0.35)$ & $13.0(0.37)$ & $12.4(1.04)$ & $11.8(0.56)$ & $12.9(0.29)$ \\
\hline Flow $(\mathrm{m} / \mathrm{s})$ & $0.8(0.24)$ & $0.4(0.15)$ & $0.7(0.14)$ & $0.6(0.43)$ & $0.1(0.13)$ & $0.6(0.21)$ \\
\hline Spec. Cond. (uS/cm) & $448.6(69.7)$ & $445.1(69.4)$ & $439.9(73.0)$ & $435.4(66.6)$ & $353.9(97.7)$ & $383.4(56.4)$ \\
\hline \multicolumn{7}{|c|}{ December 12, 2002 - March 17, 2003} \\
\hline Temp. $\left({ }^{\circ} \mathrm{C}\right)$ & $3.1(1.34)$ & $3.4(1.23)$ & $3.3(1.34)$ & $3.3(1.14)$ & $3.1(1.59)$ & $3.6(0.98)$ \\
\hline D. O. (mg/L) & $10.4(2.19)$ & $10.9(2.03)$ & $10.7(2.00)$ & $10.3(2.24)$ & $10.4(2.69)$ & $11.7(2.19)$ \\
\hline Flow $(\mathrm{m} / \mathrm{s})$ & $0.5(0.30)$ & $0.2(0.16)$ & $0.5(0.25)$ & $0.5(0.33)$ & $0.1(0.11)$ & $0.6(0.19)$ \\
\hline Spec. Cond. (uS/cm) & $433.8(62.8)$ & $434.2(60.5)$ & $435.7(70.0)$ & $444.4(53.8)$ & $377.2(86.6)$ & $415.0(46.8)$ \\
\hline
\end{tabular}




\section{Chapter 3. Juvenile Use of a Large River Embayment during Winter}

Abstract

The severity of winter conditions regulates juvenile fish mortality rates.

Identifying habitats used by juveniles is essential for understanding where fishes survive during winter. Shallow, low-gradient, off-channel embayments, like Little Sandy Creek adjacent to the Ohio River, are ideal refuges for overwintering juvenile species. Eightyfive percent of all fishes collected in Little Sandy Creek embayment during this study were juveniles. Many of the fishes collected were juvenile sunfish (Centrarchidae). Bluegill, Lepomis macrochirus, and white crappie, Pomoxis annularis, were the dominant sunfishes collected. Protecting and modifying embayment habitats may reduce juvenile mortality during winter and improve recreational angling opportunities for sunfish in large river systems.

\section{Introduction}

Winter, a critical period for juvenile riverine fishes in temperate climates, reduces probabilities of survival (Bodensteiner and Lewis 1992; Lyons 1997) and recruitment (Oliver et al. 1979; Toneys and Coble 1979; Miranda and Hubbard 1994). Fishes enter a torpor-like state during low winter temperatures (Crawshaw 1984) where metabolic rates and consequently, respiration and activity rates are low (Bodensteiner and Lewis 1992; Carlson 1992; Cunjak 1996). Fishes increase fat-reserves before winter; hence, reducing mortality associated with energy depletion (Post and Evans 1989; Cargnelli and Gross 1996). During torpor, however, juvenile fishes are susceptible to predation (Garvey et al. 1998) and adverse physiochemical conditions, such as low dissolved oxygen concentrations and strong current velocities (Cunjak 1996). Consequently, optimal 
winter habitats should provide protection from predators as well as amiable abiotic conditions that minimize energy depletion (Crawshaw 1984).

Riverine fishes overwinter in areas of low flow and relatively warm temperatures (Logsdon 1993; Bodensteiner and Lewis 1994; Johnson et al. 1998), such as off-channel coves, backwaters, marinas, embayments and industrial warm-water outflows (Sheehan et al. 1990; Gent et al. 1995; Knights et al. 1995; Raibley et al. 1997; Sheehan and Rasmussen 1999). Although riverine fishes select thermal refuges and areas of relatively low flow during winter, high winter mortality rates of juvenile fishes have been documented (Bodensteiner and Lewis 1992; Lyons 1997). Rates of juvenile survival influence numbers of individuals recruited into future fisheries (Toneys and Coble 1979; Miranda and Hubbard 1994). Given the link between winter temperature and fish mortality, and the importance of juvenile survival to fishery recruitment, fishery managers need to locate and protect winter refuge habitats of juvenile fishes.

In the Ohio River, channelization and impoundment from lock and dams have homogenized habitats, and reduced low-velocity mainstem habitats. However, embayments, shallow off-channel areas, offer low-velocity habitat for fishes during winter. Embayments contain riverine fishes during winter (Sheehan et al. 1990; Gent et al. 1995; Knights et al. 1995; Raibley et al. 1997), but their importance in the Belleville Pool of the Ohio River was undocumented before this study.

\section{Objectives}

Our primary objective was to examine species composition and size classes (juveniles vs. adults) of fishes in Little Sandy Creek embayment, Belleville Pool, Ohio River, West Virginia, during winter 2002-2003. A secondary objective was to quantify 
age-length relationships of white crappie, Pomoxis annularis, a popular sport fish for recreational anglers. This study was part of a larger evaluation of winter habitats used by fishes in main channels, island back channels, island heads and tails, and tributary mouths within Belleville Pool (see Chapter 2).

Study site

Little Sandy Creek drains 26 sq. $\mathrm{km}$ and includes a 12.4 ha embayment (39 $13^{\circ}$ ' $\left.57^{\prime \prime} \mathrm{N}, 81^{\circ} 41^{\prime} 10^{\prime \prime} \mathrm{W}\right)$ near its confluence with the Ohio River. The embayment reaches a maximum $2 \mathrm{~m}$ channel depth, but is mostly shallow $(<0.5 \mathrm{~m})$ during normal flows. The riparian zone is a mixture of agricultural fields, mixed deciduous forest, and housing developments.

\section{Methods}

Data collection

During the winter of 2002-2003, we electrofished (Smith-Root pulsed DC electrofishing boat) Little Sandy Creek embayment on 15 December 2002, and 1 and 17 March 2003. On each sample date, we electrofished two near-shore transects and one mid-channel transect. Transects were sampled for 10 minutes (peddle time). Ice cover prevented sampling during January and February. Fishes were captured, identified to species, measured (nearest $\mathrm{mm}$ total length, TL), and weighed. Weights for large fishes (over $1 \mathrm{~kg}$ ) were taken to the nearest $25 \mathrm{~g}$ with a Pesola spring scale (5 $\mathrm{kg}$ maximum). Smaller fishes (less than $1 \mathrm{~kg}$ ) were weighed to the nearest $1 \mathrm{~g}$ with a Homs spring dial scale ( $1 \mathrm{~kg}$ maximum). After measuring the weights and lengths of 100 individuals of a species collected during a single sample date, the remaining individuals were counted, (except for emerald shiner, Notropis atherinoides, due to its extremely small size). When 
collected, five white crappie individuals from each $50 \mathrm{~mm}$ size class were kept during each sample date for age analysis.

To describe the abiotic conditions of Little Sandy Creek embayment, we measured specific conductivity, dissolved oxygen (D. O.), $\mathrm{pH}$, and temperature with an YSI 6820 during each sample date. Additionally, we estimated turbidity (secchi disk, and NTUs with YSI 6820), and flow velocity (Marsh-McBirney Flowmate 2000). Length-at-maturity and age analysis

To evaluate the importance of Little Sandy Creek embayment to juvenile fishes, we defined juveniles (except white crappie) based on published length-at-maturity data from Trautman (1981), Mittelbach (1984), Etnier and Starnes (1993), Jenkins and Burkhead (1993), and Johnson and Jennings (1998). We defined white crappie individuals as juveniles or adults based on our age estimates.

We examined age structure of white crappie with otoliths. Otoliths were removed from a subset of the white crappie, sectioned with an Isomet 1000 precision saw with a $12.7 \mathrm{~cm} \times 0.4 \mathrm{~mm}$ blade, and viewed with a dissecting scope. Two observers estimated age independently, and a third observer resolved discrepancies. In order to simplify the aging process because these fish were collected in winter, we assumed January 1 as the birth date (DeVries and Frie 1996) and assigned ages as if all individuals were collected on or after January 1.

Statistical analysis

We used length-frequency distributions for the five most abundant species and compiled the information from the sources listed above for the least abundant species to establish juvenile length ranges for all species collected in Little Sandy Creek 
embayment. We calculated the proportion of juveniles of each species by sampling dates. To further classify the age-length distribution of white crappie, the length range, mean length, and variance were calculated for each white crappie age class.

Results

Abiotic conditions

Water temperatures rose from 2.95 to $11.24{ }^{\circ} \mathrm{C}$ between 1 and 17 March 2003 . During the 15 December 2002 sample, the water temperature was $4.08^{\circ} \mathrm{C}$. Dissolved oxygen ranged from 11.16 to $11.75 \mathrm{mg} / \mathrm{L}$. Specific conductivity $(\mathrm{uS} / \mathrm{cm})$ values were $257.3,257$, and 350 , and $\mathrm{pH}$ values were $6.9,7.3$, and 7.7 during the first, second, and third sample dates, respectively. A null flow velocity measurement $(0 \mathrm{~m} / \mathrm{s})$ was recorded during all three sample dates. Turbidity (NTU) was lowest during the March 1 sample (55) and highest during the March 17 sample (84). Secchi disk readings corresponded with the turbidity measurements, the highest value recorded during March $1(39 \mathrm{~cm})$ and the lowest during March $17(25 \mathrm{~cm})$.

Fish species and abundance

Juveniles represented the majority of the individuals collected in the Little Sandy Creek embayment during winter. Eighty-five percent of all fishes collected were juveniles (Table 2). The five most abundant species, gizzard shad, Dorosoma cepedianum, bluegill, Lepomis macrochirus, emerald shiner, white crappie, and orangespotted sunfish, Lepomis humilus, represented $96 \%$ of the total catch (Table 2). Of these five most abundant species, juveniles represented $83 \%$ of the total individuals. The length frequency distributions for these five species also show that shorter individuals (juveniles) were more numerous than longer individuals (Figure 6). Nearly all (97\% and 
94\%, respectively) of the gizzard shad and orangespotted sunfish individuals were juveniles (Table 2). Of the 305 centrarchid individuals collected, $81 \%$ were juvenile. Interestingly, the proportion of the total individuals represented by juveniles decreased during the March 1 and 17, 2003 sample dates (Table 2).

Seventeen species were collected during the three sampling periods (Table 2). Fish numbers differed among sample periods (717 individuals on 15 December, 52 on 1 March, and 121 on 17 March) (Table 2). The most abundant fish, gizzard shad, was only collected in large abundance during a single sample date, December 15. One each of bowfin, Amia calva, mosquitofish, Gambusia affinis, and smallmouth buffalo, Ictiobus bubalus, were collected during all sample periods, none of which were juveniles. Only one fish, white crappie, was consistently collected in relatively equal numbers and abundance (Table 2).

Five different size classes of white crappie were collected representing age classes one through five (Table 3 and Figure 6d). Eighteen age-one (juvenile) white crappie represented $29 \%$ of the aged individuals. Age-two white crappies were most abundant, representing $40 \%$ of the aged individuals. Age-three, four, and five white crappies consisted of $14.5 \%, 8 \%$, and $8 \%$, respectively, of the aged individuals.

\section{Discussion}

The Little Sandy Creek embayment, a shallow off-channel, low velocity habitat, provides an important winter refuge for juvenile fishes. The upper Ohio River, with steep topography and a restricted channel, lacks the slow-moving isolated sloughs found in other large river systems in temperate North America. Embayments in the upper Ohio River, however, are similar in abiotic characteristics to other large river backwater 
habitats that are important overwintering habitats for fishes of all ages (Sheehan et al. 1990; Gent et al. 1995; Knights et al. 1995; Raibley et al. 1997; Sheehan and Rasmussen 1999). Previous to this study, the value of these shallow, low-velocity, off-channel habitats, specifically for overwintering juvenile fishes, was undocumented.

The shallow, low-gradient physical characteristics of embayments make them ideal refuges for overwintering fishes. However, reductions in flow velocities in backwaters and embayments coupled with ice-cover can lead to low D. O. concentrations (Bodensteiner and Lewis 1992; Knights et al. 1995; Johnson et al. 1998). This reduction in D. O. content may either cause mortality in fishes or force them to seek alternative overwintering refuges in other habitat types. We do not know whether or not D. O. levels decreased below sufficient levels for fishes during the ice cover event in January and February 2003, but the measured D. O. concentrations were above critical minimal values before and after ice cover in Little Sandy Creek. Regardless of flow conditions, when temperatures fall below $4{ }^{\circ} \mathrm{C}$, fishes may prefer warmer habitats, if available. In laboratory settings, Sheehan et al. (1990) reported temperature preferences of $>4{ }^{\circ} \mathrm{C}$ for many species in large rivers, such as green sunfish, Lepomis cyanellus, bluegill, and freshwater drum, Aplodinotus grunniens. Our data collected on species residing in the mainstem portions of the Ohio River show that some fishes will select higher-velocity warmer habitats over lower velocity colder habitats during winter (see Chapter 2). Increased mortality of fishes may occur because they cannot survive the low temperatures or dissolved oxygen concentrations in an embayment, forcing them to inhabit suboptimal habitats in the mainstem portions of large rivers. Fishery managers can modify 
embayments to better suit the abiotic requirements of overwintering fishes to avoid increased mortalities due to these factors.

Given that centrarchids are popular game fishes, recreational fishery managers may want to consider the importance of embayments as overwintering sites for juvenile centrarchids of all ages, (but especially juveniles since they are the most susceptible to winter mortality), and protect these habitats. In our study, eight of the 17 species were comprised primarily juveniles of bluegill, green sunfish, orangespotted sunfish, pumpkinseed, Lepomis gibbosus, warmouth, Lepomis gulosus, white crappie, black crappie, and largemouth bass, Micropterus salmoides. Juvenile and adult white crappie used Little Sandy Creek embayment during winter, stressing the importance of this habitat for this species. Adult centrarchids use embayments during winter because of the low flow velocities (Oliver et al. 1979; Knights et al. 1995; Johnson et al. 1998; Jackson and Noble 2000). Juvenile centrarchids may use embayment habitats during winter to avoid predation. Santucci and Wahl (2003) reported $75 \%$ to $85 \%$ mortality rates during the first winter of young-of-the-year bluegills due to predation by largemouth bass. We captured few large predatory fishes during our samples, and juveniles were primarily associated with near-shore structure (overhanging vegetation, woody debris, and undercut banks). The use of structure by juveniles to avoid predation is well documented (Mittelbach 1988; Gotceitas 1990; Miranda and Hubbard 1994). The addition of woody debris into embayments would increase the amount of cover offering escape from predation, possibly increasing survival of juveniles.

A reduction of the proportion of juveniles in Little Sandy Creek embayment during the course of this study may have been due to mortality loss from the severely 
cold temperatures during the winter of 2002-2003. High winter mortality rates of juvenile freshwater drum in the Mississippi River have been documented when water temperatures approached $0{ }^{\circ} \mathrm{C}$ (Bodensteiner and Lewis 1994). We believe water temperatures within Little Sandy Creek embayment approached $0{ }^{\circ} \mathrm{C}$ during ice-cover in January and February. Low levels of dissolved oxygen during ice-cover of backwater areas have increased mortality of fishes (Bodensteiner and Lewis 1992; Knights et al. 1995; Johnson et al. 1998). These critically low temperatures (coupled with possible reductions in D. O. concentrations) may have led to increased mortality, which explains the reduction in the numbers of total individuals present in early March, after the embayment thawed.

Increasing flow rates to minimal levels $(>0)$ in embayments could limit mortality losses due to insufficient dissolved oxygen levels. Knights et al. (1995) showed that overwintering bluegill and black crappie, Pomoxis nigromaculatus, required flow velocities $>0 \mathrm{~cm} / \mathrm{s}$, but $\leq 1 \mathrm{~cm} / \mathrm{s}$ to ensure dissolved oxygen concentrations $>2 \mathrm{mg} / \mathrm{L}$ in backwater lakes of the Mississippi River. Increasing flows $>1 \mathrm{~cm} / \mathrm{s}$ rendered these habitats unsuitable to these centrarchid species (Knights et al. 1995; Johnson et al. 1998). In the Ohio River, reduction in the elevation of the impounded pool of water during freezing temperatures would allow minimal flows in and out of embayments, reducing the probability of hypoxia. Care would need to be taken to avoid releasing water so quickly that flow velocities in the embayments carry fishes (especially juveniles) out of these areas into the main channel of the river. Extended research into the specific flow velocity requirements of fishes during winter would provide more insight into how embayments can be manipulated in order to improve juvenile survival during winter. 
In summary, the severity of winter conditions regulates juvenile fish mortality rates (Bodensteiner and Lewis 1994; Post et al. 1998; Wright et al. 1999; Fullerton et al. 2000; Jackson and Noble 2000). Shallow low-velocity embayments offer a refuge for juvenile fishes so as to improve their probability of survival during winter. Protection, creation, and modification of embayment habitats may reduce juvenile mortality and spur increased sunfish production in large river systems by providing critical overwintering habitat. Whether modified or not, those embayment habitats that offer low current velocities $(\leq 1 \mathrm{~cm} / \mathrm{s})$, warmer temperatures $\left(\geq 4{ }^{\circ} \mathrm{C}\right)$, and sufficient dissolved oxygen levels ( $\geq 2 \mathrm{mg} / \mathrm{L}$ ), can be beneficial to overwintering juvenile fishes. 


\section{Literature cited}

Bodensteiner, L. R., and W. M. Lewis. 1992. Role of temperature, dissolved oxygen, and backwaters in the winter survival of freshwater drum (Aplodinotus grunniens) in the Mississippi River. Canadian Journal of Fisheries and Aquatic Sciences 49: 173-184.

Bodensteiner, L. R., and W. M. Lewis. 1994. Downstream drift of fishes in the upper Mississippi River during winter. Journal of Freshwater Ecology 9:45-56.

Cargnelli, L. M., and M. R. Gross. 1996. The temporal dimension in fish recruitment: birth date, body size, and size-dependent survival in a sunfish (bluegill: Lepomis macrochirus). Canadian Journal of Fisheries and Aquatic Sciences: 53: 360-367.

Carlson, D. M. 1992. Importance of wintering refugia to the largemouth bass fishery in the Hudson River estuary. Journal of Freshwater Ecology 7(2):173-180.

Crawshaw, L. I. 1984. Low temperature dormancy in fish. American Journal of Physiology 246:479-486.

Cunjak, R. A. 1996. Winter habitat of selected stream fishes and potential impacts from land-use activity. Canadian Journal of Fisheries and Aquatic Sciences 53:267-

DeVries, D. R., and R. V. Frie. 1996. Determination of age and growth. Pgs. 483-512 in Fisheries techniques, $2^{\text {nd }}$ edition. B. R. Murphy and D. W. Willis, editors.

American Fisheries Society, Bethesda, Maryland.

Fullerton, A. H., J. E. Garvey, R. A. Wright, and R. A. Stein. 2000. Overwinter growth and survival of largemouth bass: interactions among size, food, origin, and winter severity. Transactions of the American Fisheries Society 129: 1-12.

Garvey, J. E., R. A. Wright, and R. A. Stein. 1998. Overwinter growth and survival of age-0 largemouth bass (Micropterus salmoides): revisiting the role of body size. Canadian Journal of Fisheries and Aquatic Sciences 55: 2414-2424.

Gent, R., J. Pitlo, Jr., and T. Boland. 1995. Largemouth bass response to habitat and water quality rehabilitation in a backwater of the upper Mississippi River. North American Journal of Fisheries Management 15: 784-793.

Gotceitas, V. 1990. Plant stem density as a cue in patch choice by foraging juvenile bluegill sunfish. Environmental Biology of Fishes 29: 227-232. 
Jackson, J. R., and R. L. Noble. 2000. First-year cohort dynamics and overwinter mortality of juvenile largemouth bass. Transactions of the American Fisheries Society 129: 716-726.

Johnson, B. L., and C. A. Jennings. 1998. Habitat associations of small fishes around island in the upper Mississippi River. North American Journal of Fisheries Management 18: 327-336.

Johnson, B. L., B. C. Knights, J. W. Barko, R. F. Gaugush, D. M. Soballe, and W. F. James. 1998. Estimating flow rates to optimize winter habitat for centrarchid fish in Mississippi River (USA) backwaters. Regulated Rivers Research and Management 14:499-510.

Knights, B. C., D. L. Johnson, and M. H. Sandheinrich. 1995. Responses of bluegills and black crappie to dissolved oxygen, temperature, and current in backwater lakes of the Upper Mississippi River during winter. North American Journal of Fisheries Management 15: 390-399.

Logsdon, D. E. 1993. Suitability of side channel border and wing dam habitats for fishes overwintering in Pool 26 of the Mississippi River. M.S. Thesis, Department of Zoology, Southern Illinois University, Carbondale, Illinois.

Miranda, L. E., and W. D. Hubbard. 1994. Winter survival of age-0 largemouth bass relative to size, predators, and shelter. North American Journal of Fisheries Management 14: 773-780.

Lyons, J. 1997. Influence of winter starvation on the distribution of smallmouth bass among Wisconsin streams: a bioenergetics modeling assessment. Transactions of the American Fisheries Society 126: 157-162.

Mittelbach, G. G. 1984. Predation and resource partitioning in two sunfishes (Centrarchidae). Ecology 65: 499-513.

Mittelbach, G. G. 1988. Competition among refuging sunfishes and effects of fish density on littoral zone invertebrates. Ecology 69: 614-623. 
Oliver, J. D., G. F. Holeton, and K. E. Chua. 1979. Overwinter mortality of fingerling smallmouth bass in relation to size, relative energy stores, and environmental temperature. Transactions of the American Fisheries Society 108: 130-136.

Post, J. R., and D. O. Evans. 1989. Size-dependent overwinter mortality of young-ofyear yellow perch (Perca flavescens): laboratory, in situ enclosure, and field experiments. Canadian Journal of Fisheries and Aquatic Sciences 46: 1958-1968.

Post, D. M., J. F. Kitchell, and J. R. Hodgson. 1998. Interactions among adult demography, spawning date, growth rate, predation, overwinter mortality, and the recruitment of largemouth bass in a northern lake. Canadian Journal of Fisheries and Aquatic Sciences 55: 2588-2600.

Raibley, P. T., K. S. Irons, T. M. O'Hara, K. D. Blodgett, and R. E. Sparks. 1997. Winter habitat used by largemouth bass in the Illinois River, a large riverfloodplain ecosystem. North American Journal of Fisheries Management 17: 401-412.

Santucci, V. J., and D. H. Wahl. 2003. The effects of growth, predation, and first-winter mortality on recruitment of bluegill cohorts. Transactions of the American Fisheries Society 132: 346-360.

Sheehan, R. J., W. M. Lewis, and L. R. Bodensteiner. 1990. Winter habitat requirements and overwintering of riverine fishes. Final Report, Federal Aid in Sportfish Restoration Program, Project F-79-R.

Sheehan, R. J. and J. L. Rasmussen. 1999. Large rivers. Pgs. 529-559 in Inland Fisheries Management in North America, $2^{\text {nd }}$ edition. W. A. Hubert and C. C. Kohler, editors. American Fisheries Society, Bethesda, Maryland.

Toneys, M. L., and D. W. Coble. 1979. Size-related, first winter mortality of freshwater fishes. Transactions of the American Fisheries Society 108: 415-419.

Wright, R. A., J. E. Garvey, A. H. Fullerton, and R. A. Stein. 1999. Predicting how winter affects energetics of age- 0 largemouth bass: how do current models fare? Transactions of the American Fisheries Society 128: 603-612. 
Figure 6. Length-frequencies of gizzard shad, bluegill, emerald shiner, white crappie, and orangespotted sunfish collected by pulsed DC electrofishing in the Little Sandy Creek embayment, West Virginia, during December 15, 2002 through March 17, 2003.
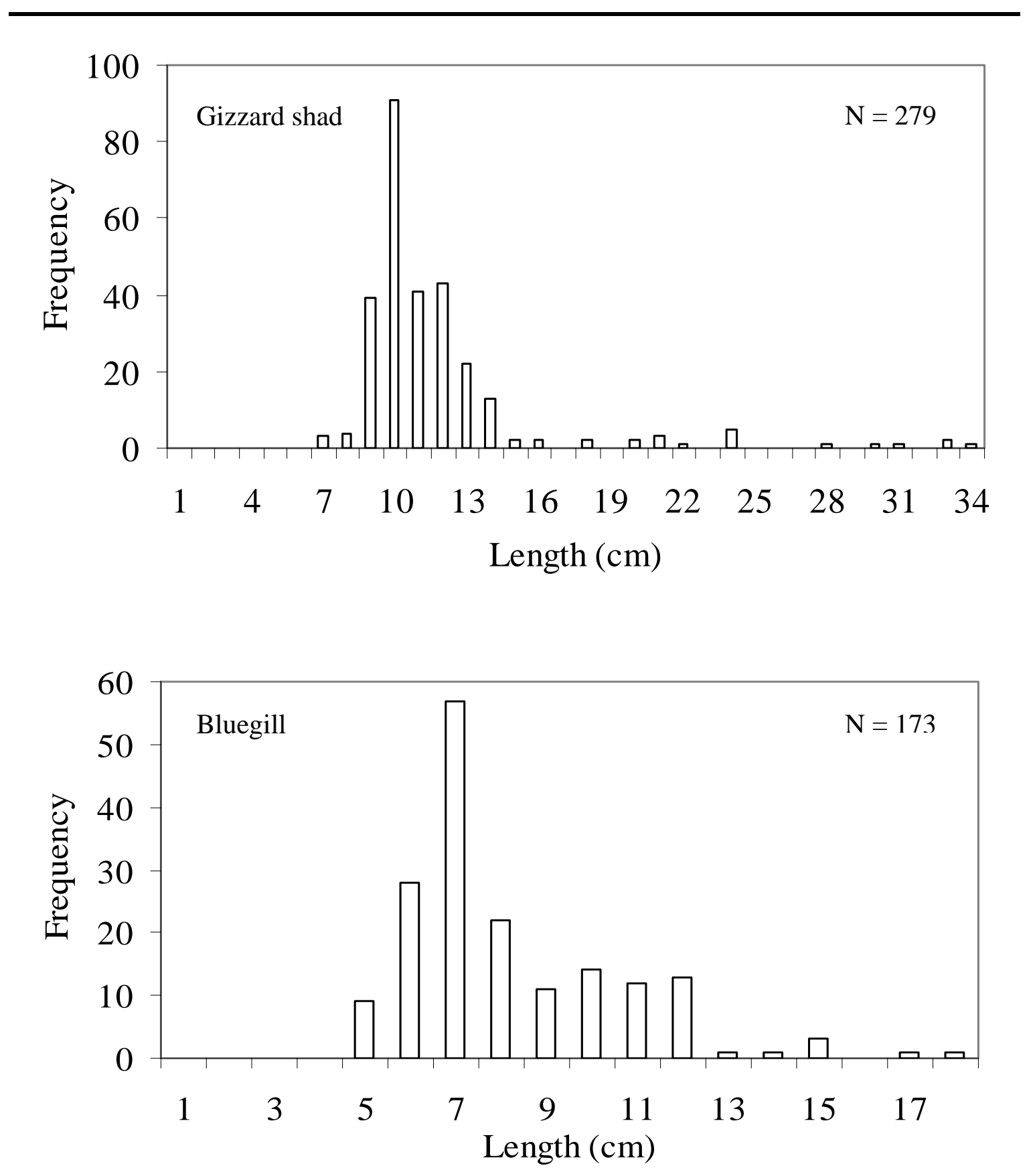

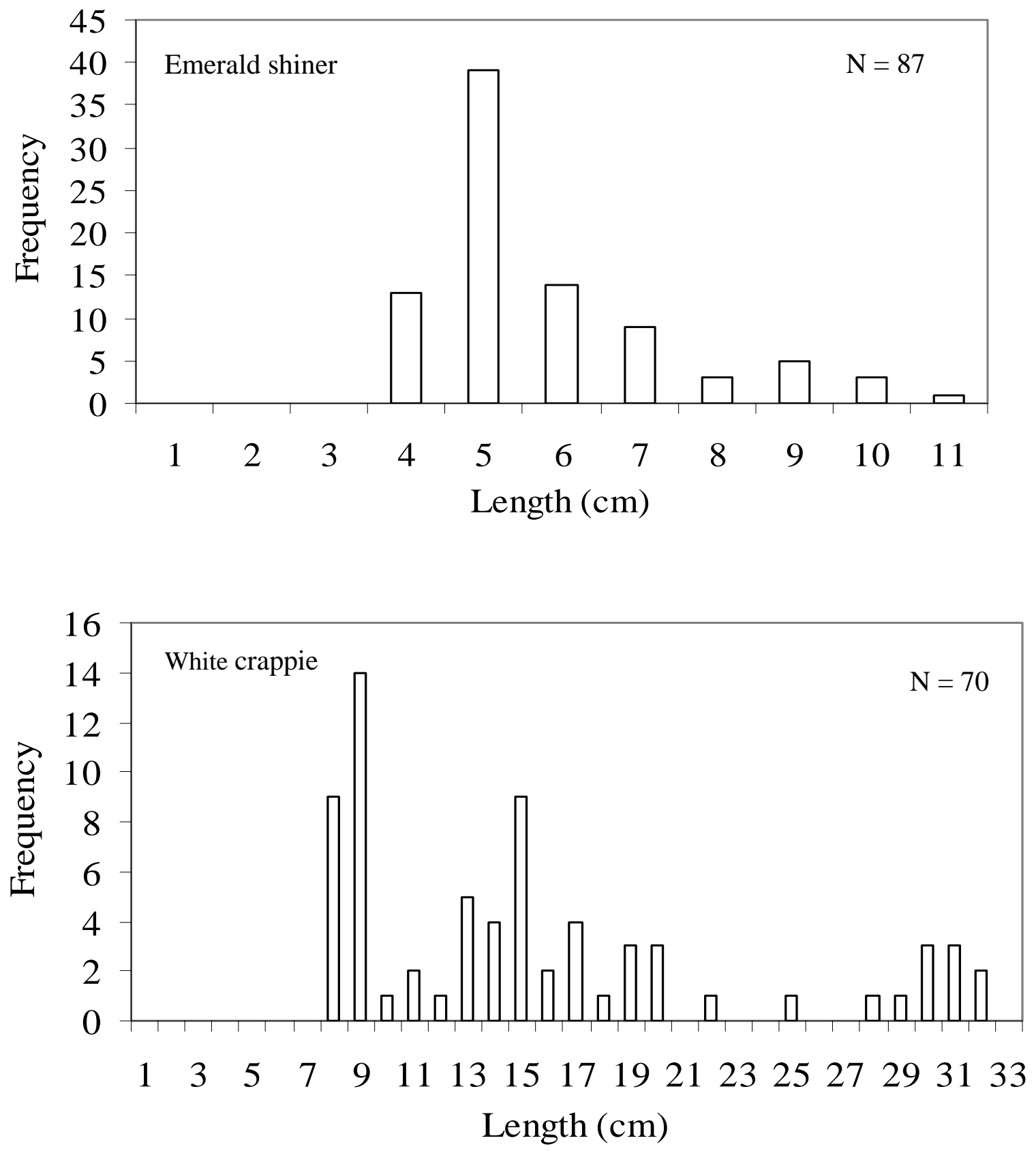


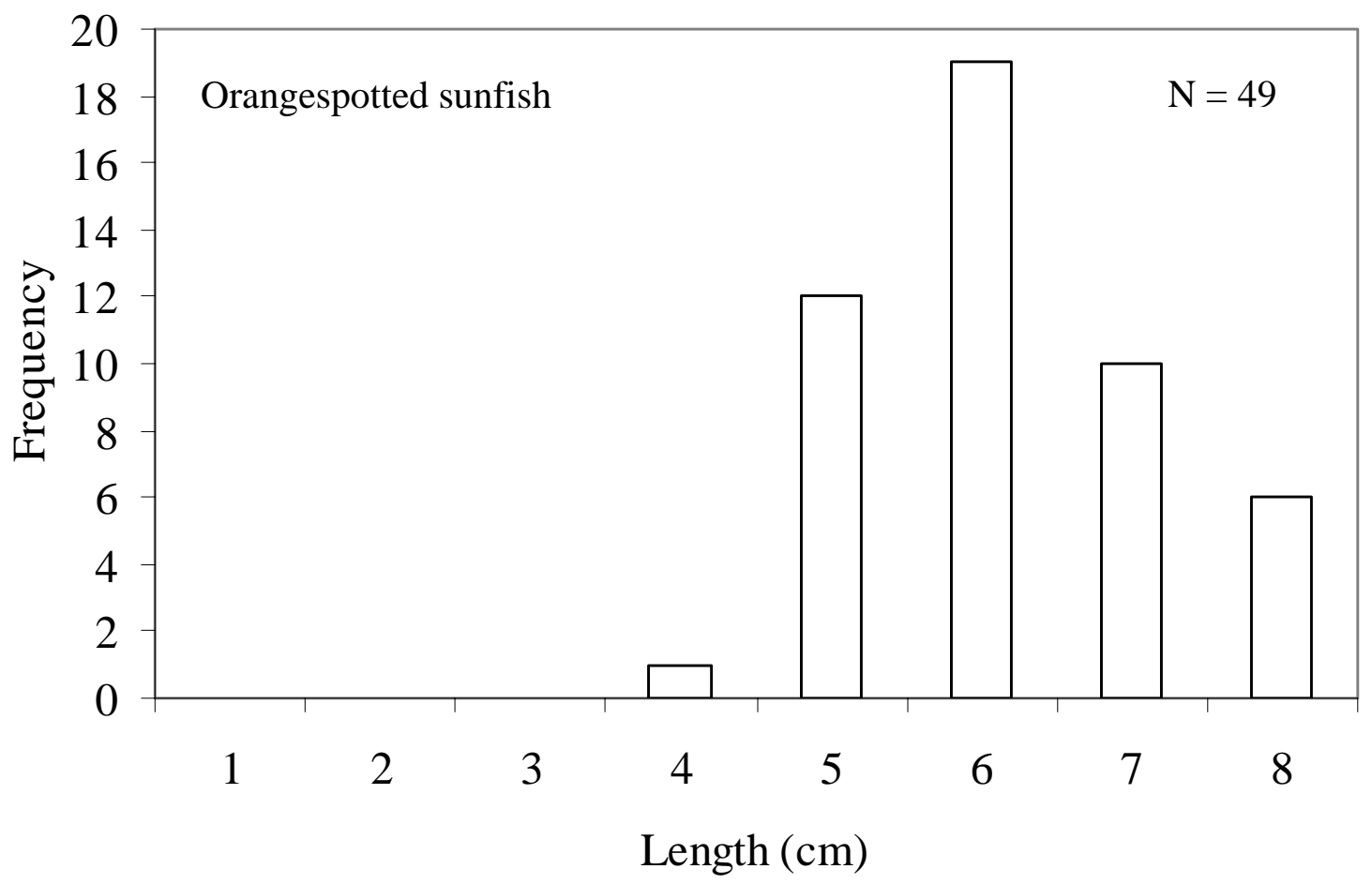


Table 2. Total number of individuals and juvenile proportion of the total for each fish species collected by pulsed DC electrofishing in the Little Sandy Creek embayment, West Virginia, during December 15, 2002 through March 17, 2003. Values in parentheses are the proportion of the total individuals represented by juveniles for that sampling date. 


\begin{tabular}{|c|c|c|c|c|c|}
\hline \multirow[b]{2}{*}{ Taxon } & \multicolumn{3}{|c|}{ Number collected } & \multirow[b]{2}{*}{ Total } & \multirow[b]{2}{*}{$\begin{array}{c}\text { Juvenile } \\
\text { proportion }\end{array}$} \\
\hline & $\begin{array}{c}\text { 15-Dec- } \\
02 \\
\end{array}$ & $\begin{array}{c}\text { 1-Mar- } \\
03 \\
\end{array}$ & $\begin{array}{c}\text { 17-Mar- } \\
03 \\
\end{array}$ & & \\
\hline Black crappie & 1 & 0 & 1 & 2 & 1 \\
\hline Pomoxis nigromaculatus & & & & & \\
\hline Bluegill & 113 & 10 & 41 & 164 & 0.85 \\
\hline Lepomis macrochirus & & & & & \\
\hline Bowfin & 0 & 0 & 1 & 1 & 0 \\
\hline Amia calva & & & & & \\
\hline $\begin{array}{l}\text { Common carp } \\
\text { Cyprinus carpio }\end{array}$ & 0 & 0 & 3 & 3 & 0 \\
\hline $\begin{array}{l}\text { Emerald shiner } \\
\text { Notropis atherinoides }\end{array}$ & 120 & 1 & 16 & 137 & 0.68 \\
\hline $\begin{array}{l}\text { Freshwater Drum } \\
\text { Aplodinotus grunniens }\end{array}$ & 4 & 0 & 2 & 6 & 0.5 \\
\hline $\begin{array}{l}\text { Gizzard shad } \\
\text { Dorosoma cepedianum }\end{array}$ & 404 & 5 & 21 & 430 & 0.97 \\
\hline $\begin{array}{l}\text { Green sunfish } \\
\text { Lepomis cyanellus }\end{array}$ & 3 & 1 & 3 & 7 & 0.29 \\
\hline $\begin{array}{l}\text { Largemouth bass } \\
\text { Micropterus salmoides }\end{array}$ & 0 & 2 & 1 & 3 & 0.33 \\
\hline $\begin{array}{l}\text { Mosquitofish } \\
\text { Gambusia affinis }\end{array}$ & 1 & 0 & 0 & 1 & 0 \\
\hline $\begin{array}{l}\text { Orangespotted sunfish } \\
\text { Lepomis humilis }\end{array}$ & 35 & 6 & 8 & 49 & 0.94 \\
\hline $\begin{array}{l}\text { Pumpkinseed } \\
\text { Lepomis gibbosus }\end{array}$ & 0 & 3 & 2 & 5 & 0.2 \\
\hline $\begin{array}{l}\text { River carpsucker } \\
\text { Carpiodes carpio }\end{array}$ & 0 & 0 & 4 & 4 & 1 \\
\hline $\begin{array}{l}\text { Smallmouth buffalo } \\
\text { Ictiobus bubalus }\end{array}$ & 0 & 0 & 1 & 1 & 0 \\
\hline $\begin{array}{l}\text { Spotted sucker } \\
\text { Minytrema melanops }\end{array}$ & 1 & 1 & 0 & 2 & 0 \\
\hline $\begin{array}{l}\text { Warmouth } \\
\text { Lepomis gulosus }\end{array}$ & 2 & 2 & 1 & 5 & 0.2 \\
\hline $\begin{array}{l}\text { White crappie } \\
\text { Pomoxis annularis }\end{array}$ & 33 & 21 & 16 & 70 & 0.79 \\
\hline Total & $717(0.92)$ & $52(0.65)$ & $121(0.44)$ & 890 & 0.83 \\
\hline
\end{tabular}


Table 3. The length range, mean length, and variance at age for white crappies collected by pulsed DC electrofishing in the Little Sandy Creek embayment, West Virginia, during December 15, 2002 through March 17, 2003.

\begin{tabular}{ccccc}
\hline Age & $\begin{array}{c}\text { Length range } \\
(\mathrm{cm})\end{array}$ & $\begin{array}{c}\text { Mean length } \\
(\mathrm{cm})\end{array}$ & $\begin{array}{c}\text { Variance } \\
(\mathrm{cm})\end{array}$ & $\begin{array}{c}\text { Number } \\
\text { collected }\end{array}$ \\
\hline 1 & $6.1-10.2$ & 7.6 & 1.1 & 18 \\
2 & $12-17.2$ & 13.8 & 2.4 & 25 \\
3 & $16.8-23.2$ & 19.4 & 5.3 & 9 \\
4 & $26.1-28.6$ & 27.4 & 0.8 & 5 \\
5 & $29.4-30.9$ & 29.4 & 0.3 & 5 \\
\hline
\end{tabular}




\section{Chapter 4. Growth Assessment of three Sport Fishes of the Ohio River}

Abstract

Channel catfish, Ictalurus punctatus, freshwater drum, Aplodinotus grunniens, and white bass, Morone chrysops, are popular sport fishes in the Ohio River. Standard age and growth statistics were computed to assess the population growth and condition of these fishes. Channel catfish reached larger mean-lengths at all ages compared to specimens collected over 30 years ago in the Ohio River. Numerous older and larger freshwater drum individuals were collected, suggesting plentiful trophy-sized individuals exist in the Ohio River. None of the white bass collected were harvestable size, suggesting larger individuals may use different habitats than smaller individuals or that environmental conditions are unsuitable for appreciable growth of this species in the Ohio River. Although the population status appears satisfactory for channel catfish and freshwater drum, more information is needed to better assess the condition of white bass in the Ohio River.

\section{Introduction}

Channel catfish, Ictalurus punctatus, freshwater drum, Aplodinotus grunniens, and white bass, Morone chrysops, are popular gamefishes of the Ohio River, West Virginia. Currently, harvest regulations for the Ohio River, West Virginia, do not restrict lengths or numbers of channel catfish and freshwater drum, but impose a daily creel limit of four white bass $>38 \mathrm{~cm}$. Little published information exists on the population dynamics of these three fishes in West Virginia waters of the Ohio River. An 
understanding of age, length, and weight relationships of these important fishes is needed to manage and maintain viable recreational fisheries (Anderson and Neumann 1996).

Channel catfish live to a maximum age of 24 years and can attain weights of 34 kg (Etnier and Starnes 1993). In 1973, Schoumacher reported a maximum mean length of $43 \mathrm{~cm}$ at age eight for Ohio River specimens. Quist and Guy (1998) also reported a maximum age of eight for channel catfish specimens from the Kansas River, but the mean length at age eight was a greater $59 \mathrm{~cm}$. Maximum ages and mean lengths reported for freshwater drum differ, however, a maximum age of 10 to 11 years and a mean length of $69 \mathrm{~cm}$ generalizes Goeman et al. (1984), Etnier and Starnes (1993), and Braaten and Guy (2002). The maximum age of white bass from Tennessee is 8 (Etnier and Starnes 1993), while Colvin (2002) recorded age-7 white bass specimens from the Missouri River. Objectives

The objective of this study was to document growth relationships of channel catfish, freshwater drum, and white bass from Belleville Pool, Ohio River, West Virginia. Age-frequency distributions, the von Bertalanffy growth equation (Ricker 1975) and the allometric growth equation are used in this analysis in order to assess the population condition, structure, and growth of these three commonly occurring sport fishes in the Ohio River.

Study site

The Belleville Pool of the Ohio River, created by Belleville Lock and Dam (rkm 328.1), extends upstream to Willow Island Lock and Dam (rkm 260.2). The $67.9 \mathrm{~km}$ pool averages $404.5 \mathrm{~m}$ wide, $7.3 \mathrm{~m}$ deep, and comprises 2850 ha of surface area 
(ORSANCO 1994). The deepest section of the pool $(15 \mathrm{~m})$ lies directly upstream of Belleville Lock and Dam. A navigation channel (3.7 $\mathrm{m}$ deep) is maintained for commercial barge traffic by the United States Army Corps of Engineers (USACE) (ORSANCO 1994). The riparian zone is a mixture of hardwood forests, urban and industrial frameworks, and agricultural settings. Most large floodplains near Belleville Pool are heavily urbanized, including cities of Parkersburg, WV (confluence of the Little Kanawha and Ohio rivers) and Marietta, $\mathrm{OH}$ (junction of Muskingum and Ohio rivers). Methods

Data collection

We sampled the Belleville Pool during two periods (February 2002 - April 2002, and December 2002 to March 2002) with a variable-depth AC electrofishing boat for water depths of 2-15 meters (Grunwald 1983, Newcomb 1989). Fishes were identified to species, measured (nearest mm total length, TL), and weighed. Large fishes (over $1 \mathrm{~kg}$ ) were weighed to the nearest $25 \mathrm{~g}$ with a Pesola spring scale (5 $\mathrm{kg}$ maximum). Smaller fishes (less than $1 \mathrm{~kg}$ ) were weighed to the nearest $1 \mathrm{~g}$ with a Homs spring dial scale $(1 \mathrm{~kg}$ maximum). When collected, five individuals from each $50 \mathrm{~mm}$ size class of channel catfish, freshwater drum, and white bass were frozen for age analysis.

Age analysis

Sagittal otoliths were extracted from freshwater drum and white bass and sectioned with an Isomet 1000 precision saw with a $12.7 \mathrm{~cm}$ x $0.4 \mathrm{~mm}$ blade (DeVries and Frie 1996). Transverse otolith sections (approximately $1 \mathrm{~mm}$ thickness) were stained with iodine. When illuminated, most small otoliths (age classes $0-2$, especially in freshwater drum) were aged without sectioning. Pectoral spines of channel catfish were 
removed and softened in $4 \%$ nitric acid solution $\left(\mathrm{HNO}_{3}\right)(\mathrm{K}$. Hartman pers. comm.). Each spine was sectioned at the distal end of the basal groove (Sneed 1951) with a singleedge razor blade. Annuli of otolith and pectoral spine sections were counted under magnification (2-4 X). Two observers estimated age independently, and a third observer resolved discrepancies. In order to simplify the aging process because these fish were collected in winter, we assumed January 1 as the birth date (DeVries and Frie 1996) and assigned ages as if all individuals were collected on or after January 1.

Mean length for each age class and the variance of these values were calculated for all species. The frequency of each age class for all species was also calculated. We used the von Bertalanffy (Ricker 1975) equation $\mathrm{L}_{\mathrm{t}}=\mathrm{L}_{\infty} *\left(1-\mathrm{e}^{(-\mathrm{K} * \mathrm{t}}{ }_{0}\right)$ ) to describe the relationship of age and length of these three species. This equation calculated $\mathrm{L}_{\mathrm{t}}$ (length at a specific age) values for channel catfish, freshwater drum, and white bass by estimating the asymptotic length $\left(\mathrm{L}_{\infty}(\mathrm{cm})\right)$, growth coefficient $(\mathrm{K})$, and $\mathrm{t}_{0}($ theoretical age in years when length $=0$ ). Standard errors of these three parameters were also calculated. We also used the allometric growth equation $\mathrm{W}=\mathrm{aL}^{\mathrm{b}}$, where $\mathrm{W}=$ weight $(\mathrm{g}), \mathrm{a}=\mathrm{y}$ intercept, and $\mathrm{b}=$ slope, and $\mathrm{L}=$ length $(\mathrm{mm})$, to describe the length-weight relationship of the three species. Standard errors of the slope and y-intercept were also calculated.

\section{Results}

Younger age classes represented the greatest proportion of individuals of white bass and freshwater drum (Figure 7). The greatest number of individuals was age-4 for channel catfish, age-1 for freshwater drum, and age-2 for white bass (Figure 7). Freshwater drum were represented by the oldest age class (22), while the oldest age classes of channel catfish and white bass were 9 and 4, respectively (Table 4). The 
longest freshwater drum individual was $77 \mathrm{~cm}, 62 \mathrm{~cm}$ for channel catfish, and approximately $30 \mathrm{~cm}$ for white bass (Table 4). Surprisingly, no white bass individuals collected were longer than the harvest minimum size limit of $>38 \mathrm{~cm}$. High variances of mean-length-at-age values occurred due to low sample sizes for older age classes of freshwater drum and most age classes of channel catfish (Table 4).

The growth parameters calculated by the von Bertalanffy and allometric growth equations varied between the three species. The von Bertalanffy growth parameter estimates are as follows: for channel catfish, the $\mathrm{L}_{\infty}=113 \mathrm{~cm}(\mathrm{SE}=1.34), \mathrm{K}=0.077$ (SE $=0.056)$, and $\mathrm{t}_{0}=1.71(\mathrm{SE}=0.46)($ Figure $8 \mathrm{a}) ;$ for freshwater drum, the $\mathrm{L}_{\infty}=118 \mathrm{~cm}(\mathrm{SE}$ $=6.82), \mathrm{K}=0.051(\mathrm{SE}=0.013)$, and $\mathrm{t}_{0}=1.47(\mathrm{SE}=0.38)($ Figure $8 \mathrm{~b})$; for white bass, the $\mathrm{L}_{\infty}=48 \mathrm{~cm}(\mathrm{SE}=3.36), \mathrm{K}=0.248(\mathrm{SE}=0.32)$, and $\mathrm{t}_{0}=1.16(\mathrm{SE}=0.21)$ (Figure $\left.8 \mathrm{c}\right)$.

The allometric growth parameter estimates are as follows: for channel catfish, the slope $=$ $3.35(\mathrm{SE}=0.268)$, and $y$-intercept $=1.0 \times 10^{-6}\left(\mathrm{SE}=2.35 \times 10^{-7}\right)($ Figure $9 \mathrm{a})$; for freshwater drum, the slope $=3.39(\mathrm{SE}=0.179)$, and $\mathrm{y}$-intercept $=1.0 \times 10^{-6}(\mathrm{SE}=1.12 \mathrm{x}$ $\left.10^{-7}\right)($ Figure 9b); for white bass, the slope $=3.13(\mathrm{SE}=0.492)$, and $\mathrm{y}$-intercept $=1.7 \mathrm{x}$ $10^{-6}\left(\mathrm{SE}=4.61 \times 10^{-7}\right)($ Figure $9 \mathrm{c})$.

\section{Discussion}

White bass growth appears to be deficient for angling harvest in the upper Ohio River. It is possible that we failed to locate larger white bass individuals in the habitats we sampled, but none of the individuals collected were greater than the minimum size limit set for harvest, $>38 \mathrm{~cm}$, by the West Virginia Department of Natural Resources (Table 4). Even though the von Bertalanffy maximum length $\left(\mathrm{L}_{\infty}\right)$ value was $48 \mathrm{~cm}$ and the growth coefficient $(\mathrm{K})$ was highest of all species, collected white bass individuals did 
not approach harvestable size. Our $\mathrm{L}_{\infty}$ value for white bass agrees with Colvin's Missouri River specimens (2002), while our K value is considerably lower, denoting that Ohio River white bass may attain relatively equal maximum sizes but at a slower rate. White bass specimens from the Roach Lake, Ohio had mean lengths (cm) of 14.0, 26.9, and 36.6 for ages 1, 2, and 3, respectively (Carlander 1997), substantially larger sizes than our Ohio River specimens (Table 4). Our mean-length-at-age estimates for the four white bass age classes measured were considerably less than those from Tennessee (Etnier and Starnes 1993), further suggesting that white bass growth in the Ohio River is limited.

Channel catfish growth is extremely variable across spatial and temporal boundaries (Etnier and Starnes 1993). Our low von Bertalanffy K value suggests channel catfish are not growing quickly in the upper Ohio River. However, our mean-length-atage estimates for channel catfish were higher for all age classes than Schoumacher's (1973) Ohio River specimens (also taken from the Belleville Pool). Mississippi River specimens were reported as having mean lengths (cm) of 15.0, 21.1, and 25.4 for ages 2, 3, and 4, respectively (Carlander 1969), also significantly less than our Ohio River specimens. However, our maximum mean length agrees with the mean-length-at-age 8 (Table 4) from Tennessee (Etnier and Starnes 1993) and Kansas River specimens (Quist and Guy 1998). This suggests that channel catfish in the upper Ohio River may be growing at a higher rate and attaining larger sizes faster than in the past.

Freshwater drum reach considerable sizes in the Belleville Pool, Ohio River. The maximum age estimate for our freshwater drum specimens (Table 4) is greater than most published information. The oldest freshwater drum individual collected in the Belleville Pool was estimated to be 22 years of age, measured $77 \mathrm{~cm}$ in length, and weighed $7.4 \mathrm{~kg}$. 
In Lake Erie, Cunningham (1989) recorded a 33-yr old freshwater drum and numerous individuals older than 10 years. A relatively large number of freshwater drum individuals collected were of older age classes $(>10)$ (Figure $7 \mathrm{~b}$ and Table 4), suggesting that conditions in the upper Ohio River are favorable for long life expectancy of freshwater drum.

In summary, the age and growth information presented here is useful in assessing the population growth and condition of these three popular sport fishes in the Ohio River. None of the white bass collected were harvestable size, possibly indicating larger white bass either use different habitats than smaller individuals or sub optimal environmental conditions exist in the Belleville Pool for this species. Channel catfish appear to be growing at faster rates than in the past, suggesting environmental conditions have improved for this species over time. The impressive sizes that freshwater drum reach in the Belleville Pool should delight any angler seeking trophy-sized individuals of this species. Hopefully, this information proves useful for fishery managers seeking to improve conditions or assess past management actions for these three sport fisheries in the Ohio River. 


\section{Literature cited}

Anderson, R. O., and R. M. Neumann. 1996. Length, weight, and associated structural indices. Pgs. 447-482 in Fisheries techniques, $2^{\text {nd }}$ edition. B. R. Murphy and D. W. Willis, editors. American Fisheries Society, Bethesda, Maryland.

Braaten, P. J., and C. S. Guy. 2002. Life history attributes of fishes along the latitudinal gradient of the Missouri River. Transactions of the American Fisheries Society 131: 931-945.

Carlander, K. D. 1969. Handbook of Freshwater Fishery Biology, Volume 1. The Iowa State University Press, Ames, Iowa.

Carlander, K. D. 1997. Handbook of Freshwater Fishery Biology, Volume 3. The Iowa State University Press, Ames, Iowa.

Colvin, M. A. 2002. Population and fishery characteristics of white bass in four large Missouri River reservoirs. North American Journal of Fisheries Management 22: 677-689.

Cunningham, P. K. 1989. Bioenergetics of freshwater drum in Lake Erie: a comparison of growth, food consumption and diets to assess inter-basin differences in prey. M. S. Thesis. The Ohio State University, Columbus, Ohio.

DeVries, D. R., and R. V. Frie. 1996. Determination of age and growth. Pgs. 483-512 in Fisheries techniques, $2^{\text {nd }}$ edition. B. R. Murphy and D. W. Willis, editors. American Fisheries Society, Bethesda, Maryland.

Etnier, D. A., and W. C. Starnes. 1993. The Fishes of Tennessee. University of Tennessee, Knoxville, Tennessee.

Goeman, T. J., D. R. Helms, and R. C. Heidinger. 1984. Comparison of otolith and scale age determinations for freshwater drum from the Mississippi River. Proceedings of the Iowa Academy of Science 91: 49-51.

Grunwald, G. L. 1983. Modification of alternating current electrofishing gear for deep water sampling. Pgs. 177-187 in Proceedings of the 39th Annual Upper Mississippi River Conservation Meeting, 16-18 March, Quincy, Illinois.

Newcomb, B. A. 1989. Winter abundance of channel catfish in the channelized Missouri River, Nebraska. North American Journal of Fisheries Management 9:195-202. 
ORSANCO (Ohio River Valley Water Sanitation Commission). 1994. Ohio River Water Quality Fact Book, Ohio River Valley Water Sanitation Commission. Cincinnati, Ohio.

Quist, M. C., and C. S. Guy. 1998. Population characteristics of channel catfish from the Kansas River, Kansas. Journal of Freshwater Ecology 13: 351-359.

Ricker, W. E. 1975. Computation and interpretation of biological statistics of fish populations. Fisheries Research Board of Canada Bulletin 191.

Schoumacher, R. 1973. Some observations on channel catfish populations in the Ohio River bordering West Virginia. Proceedings of the West Virginia Academy of Science 45: 136-145.

Sneed, K. E. 1951. A method for calculating the growth of channel catfish, Ictalurus punctatus. Transactions of the American Fisheries Society. 80: 174-183. 
Figures and Tables

Figure 7. The age frequencies of channel catfish, freshwater drum, and white bass collected in the Belleville Pool, Ohio River during February 17 through April 7, 2002 and December 12, 2002 through March 17, 2003.

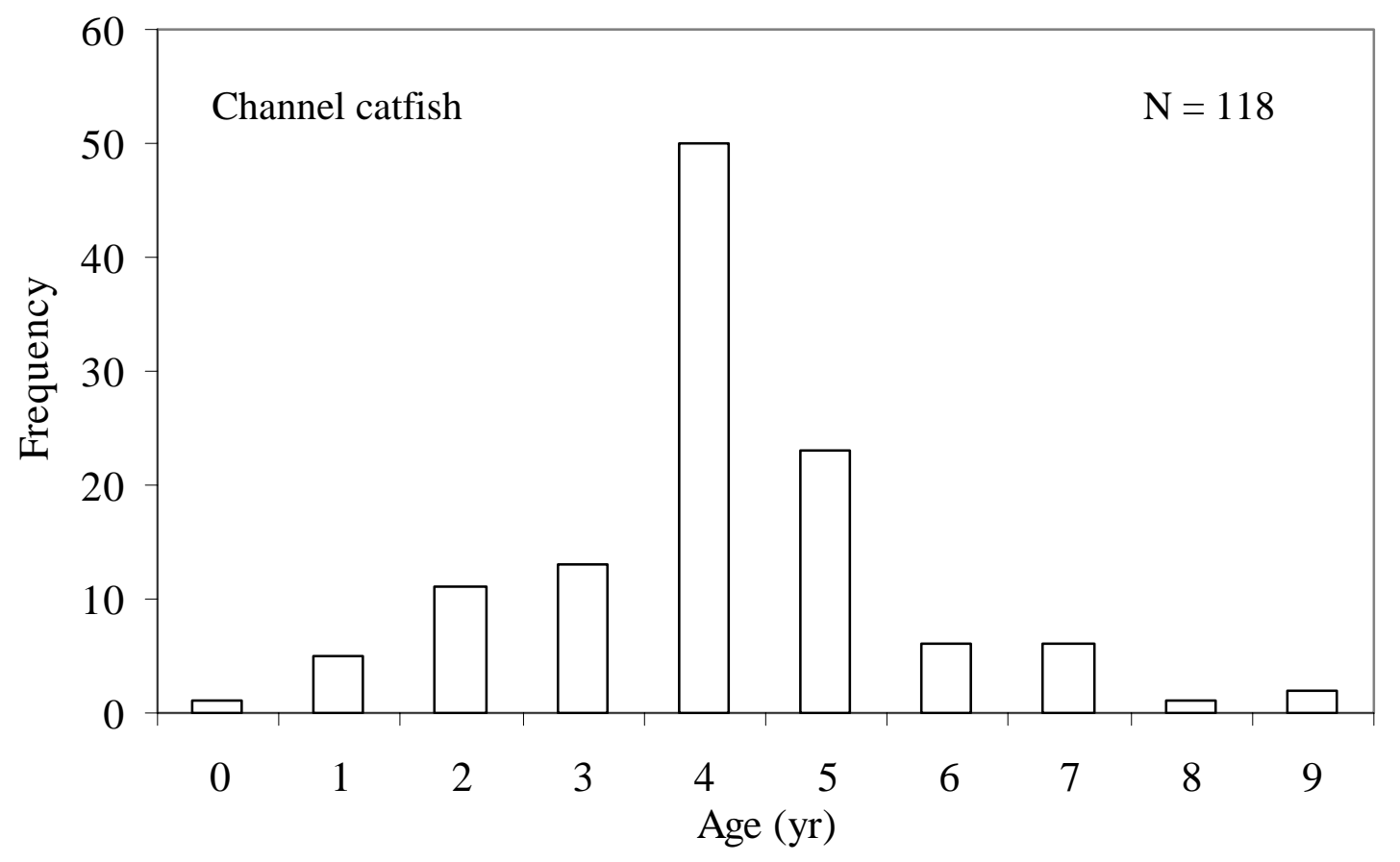



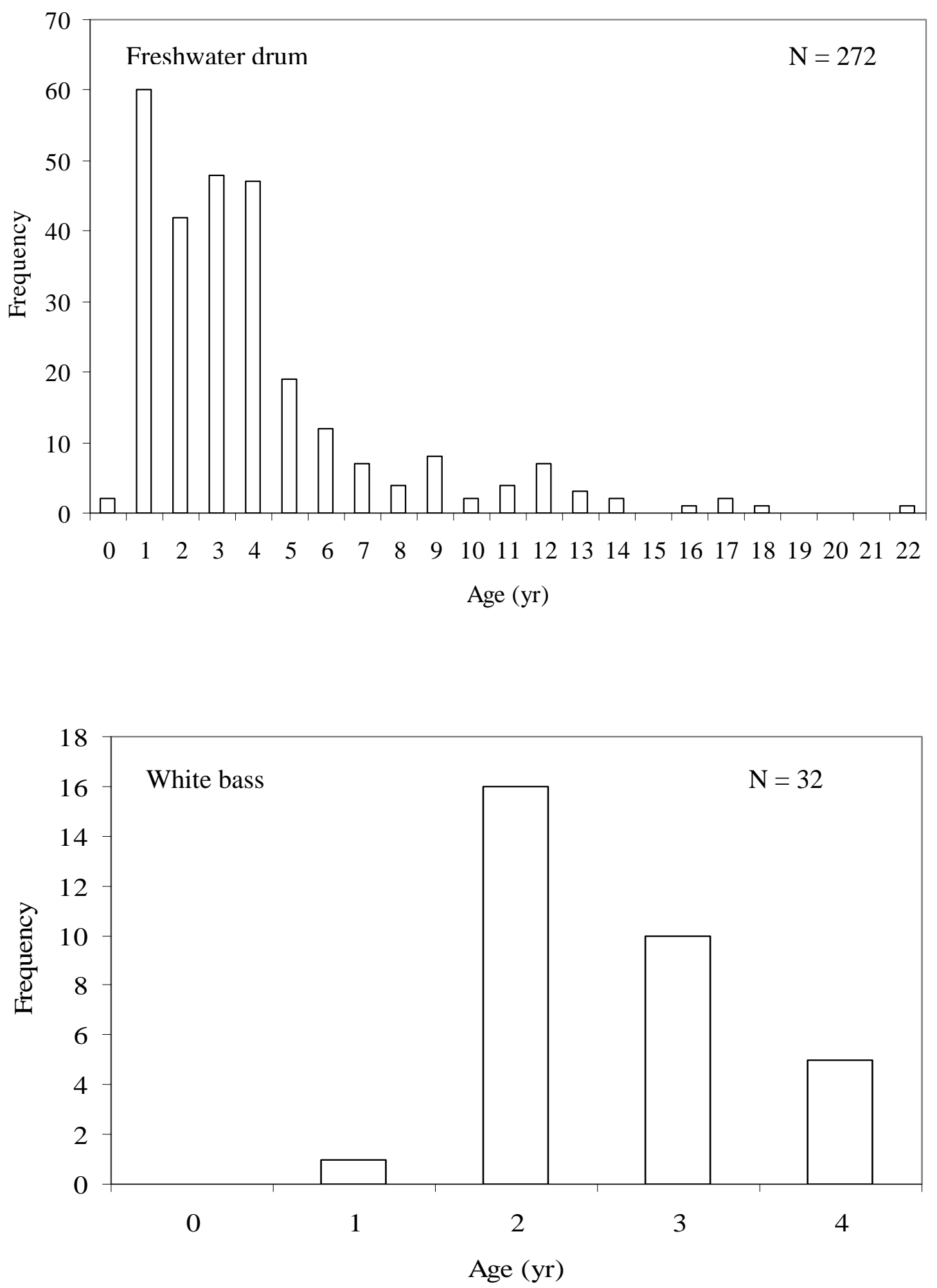
Figure 8. The von Bertalanffy growth curves of channel catfish, freshwater drum, and white bass collected in the Belleville Pool, Ohio River.

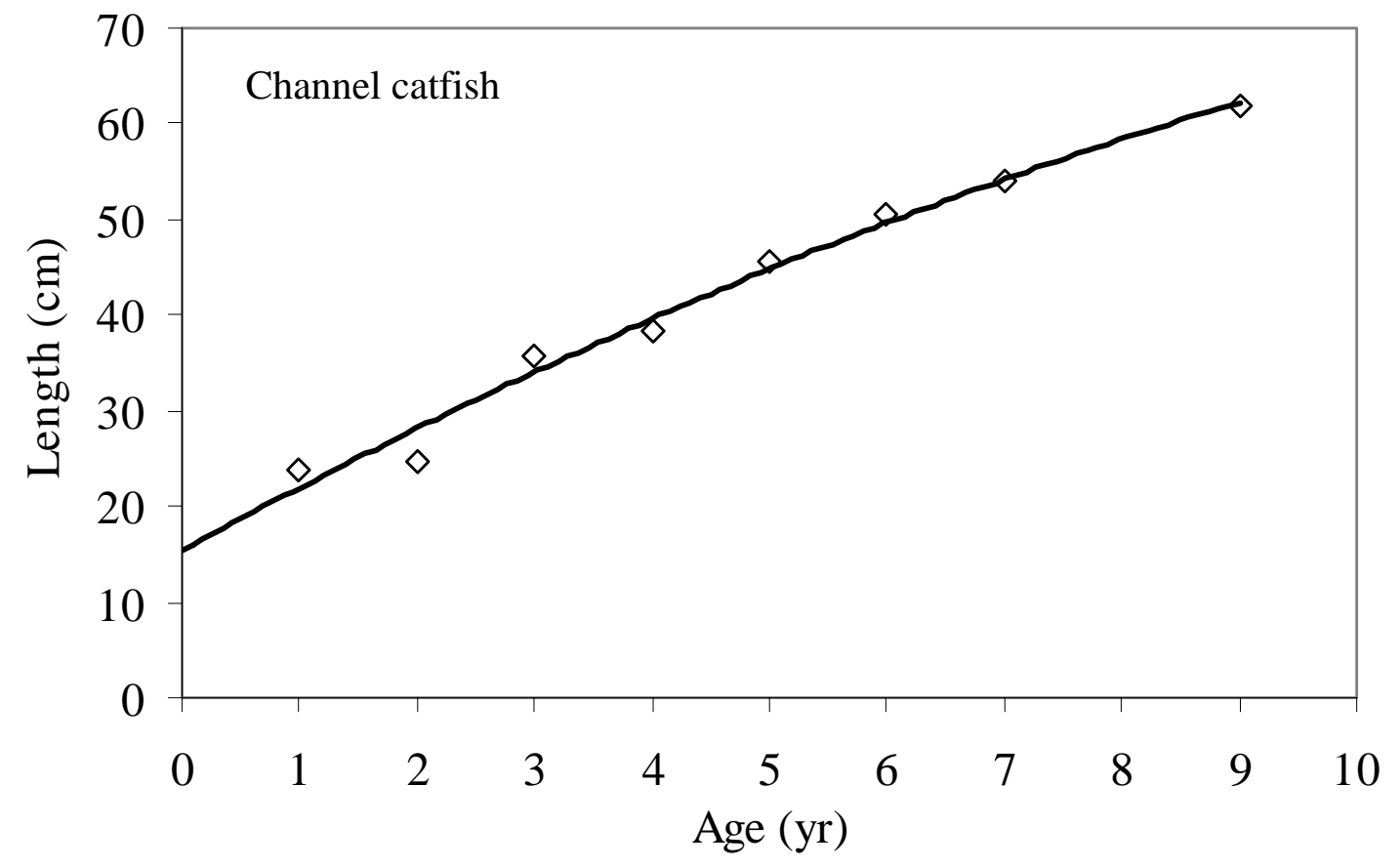



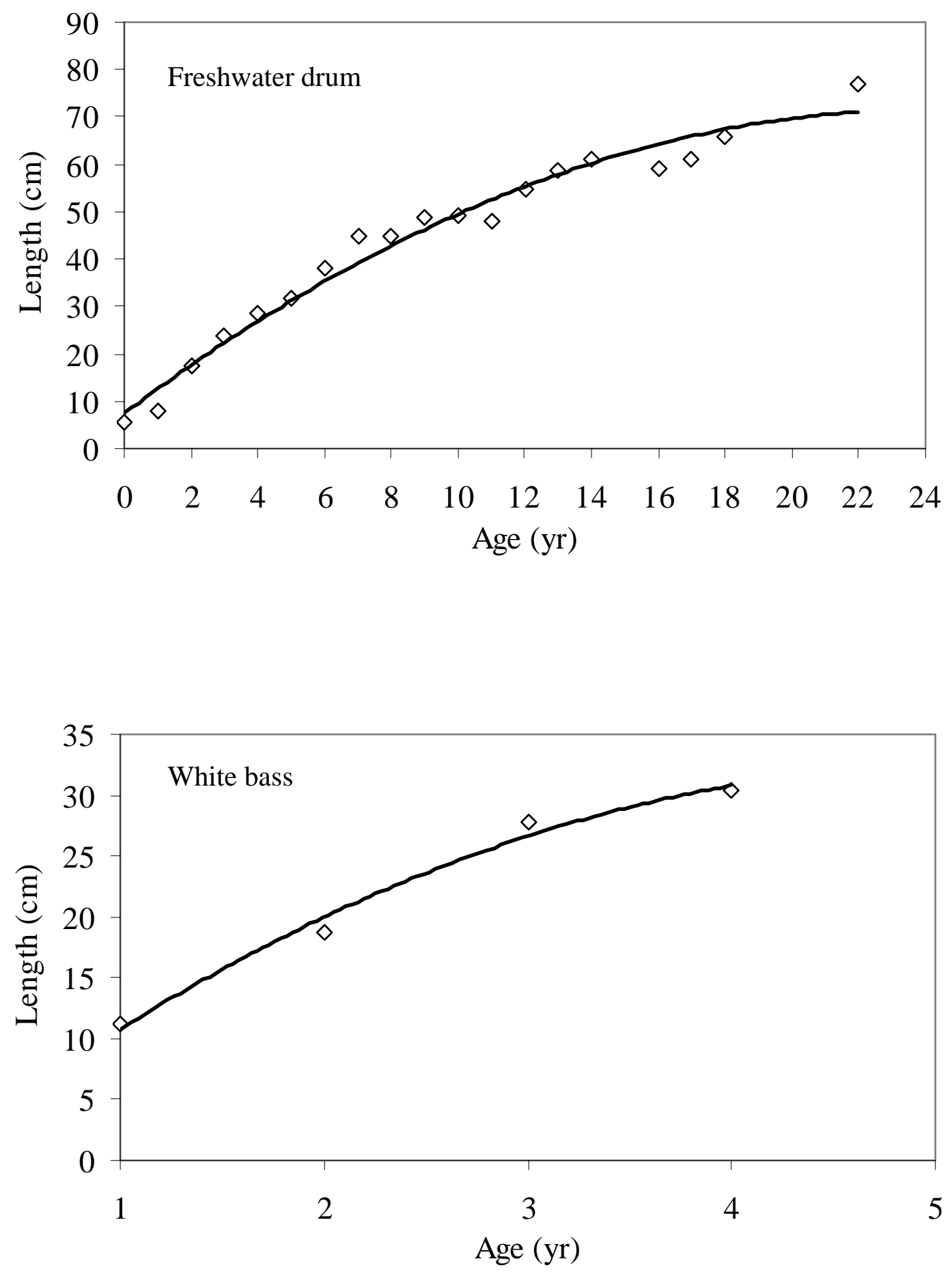
Figure 9. The allometric growth of channel catfish, freshwater drum, and white bass collected in the Belleville Pool, Ohio River.

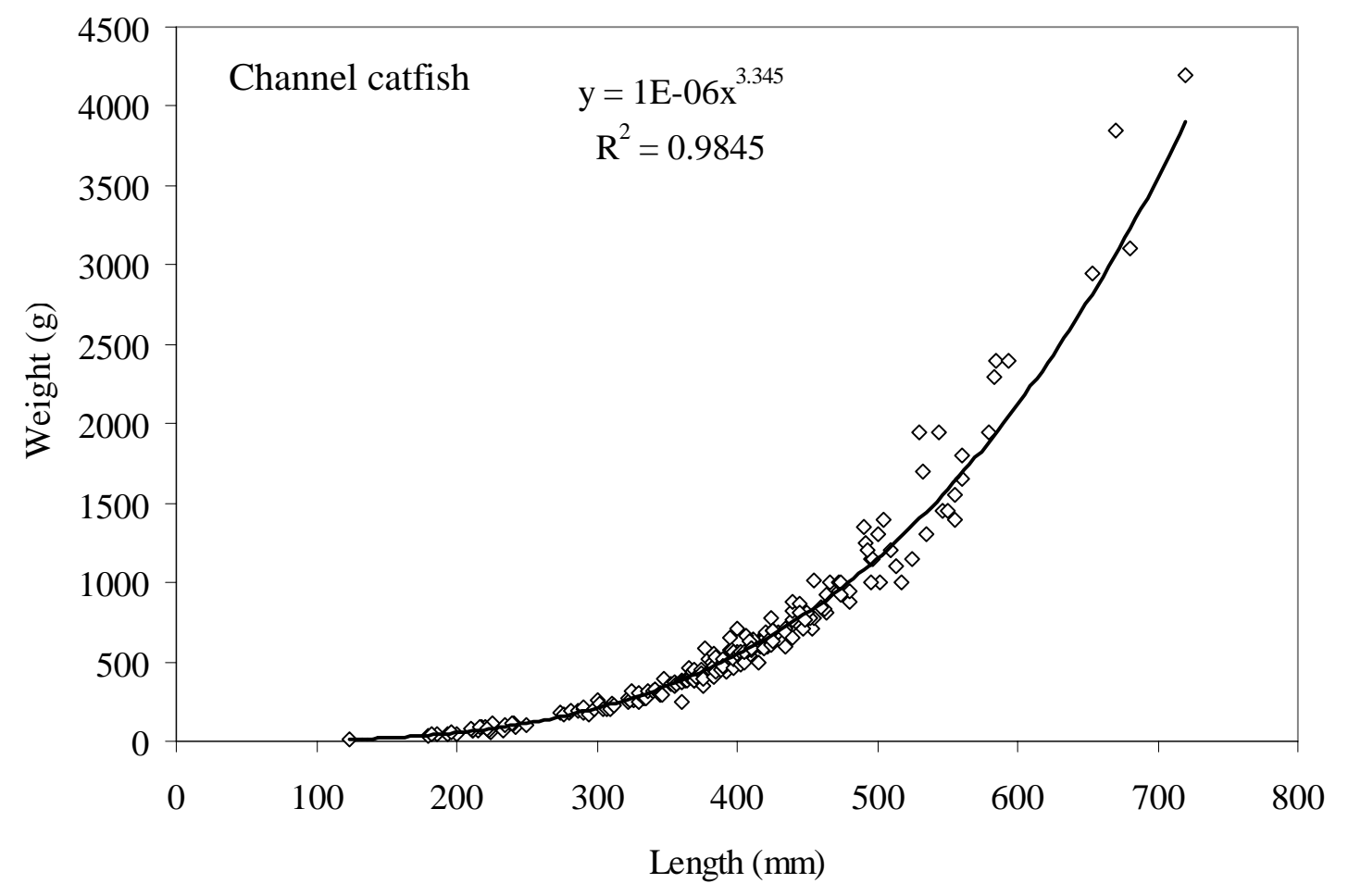




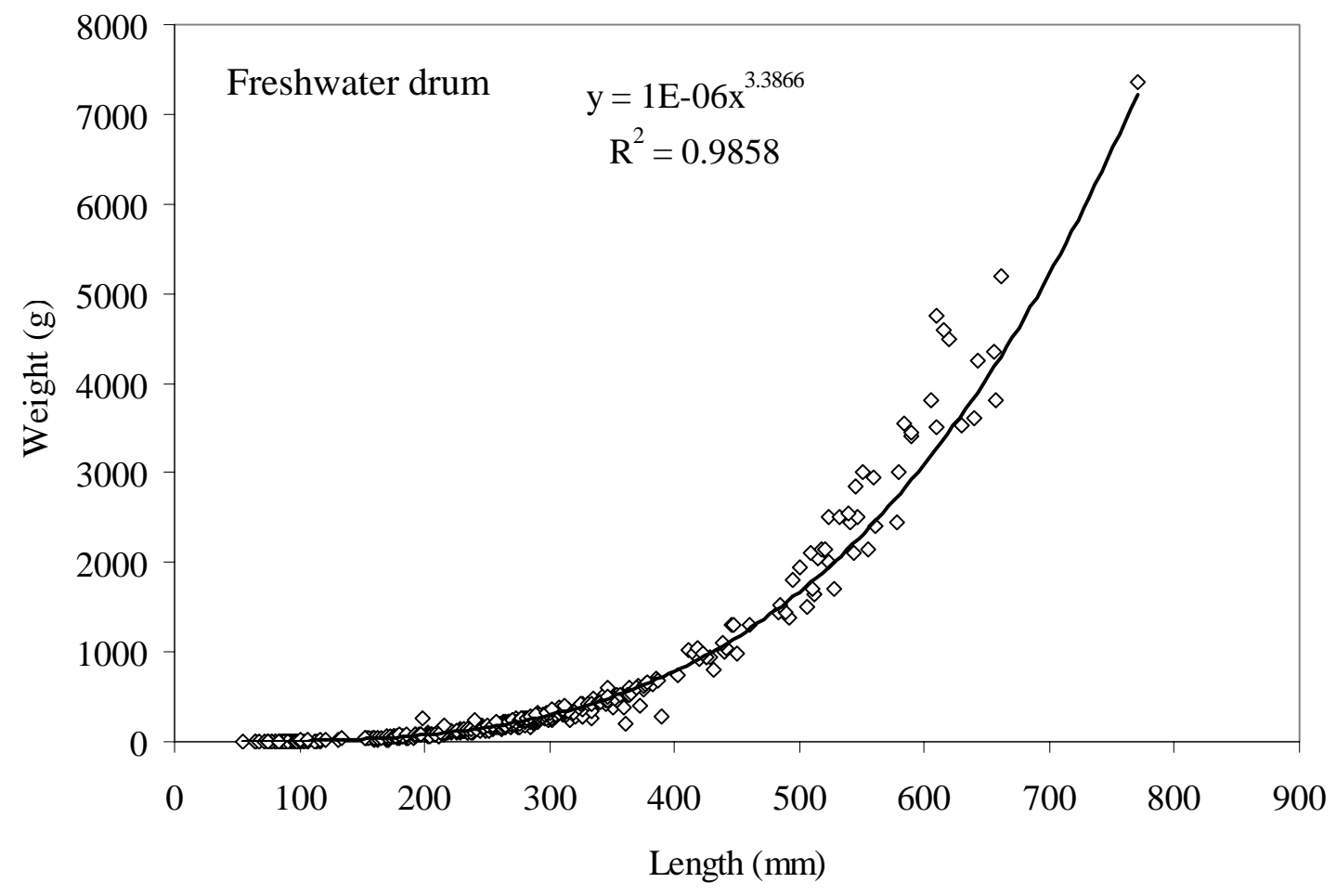




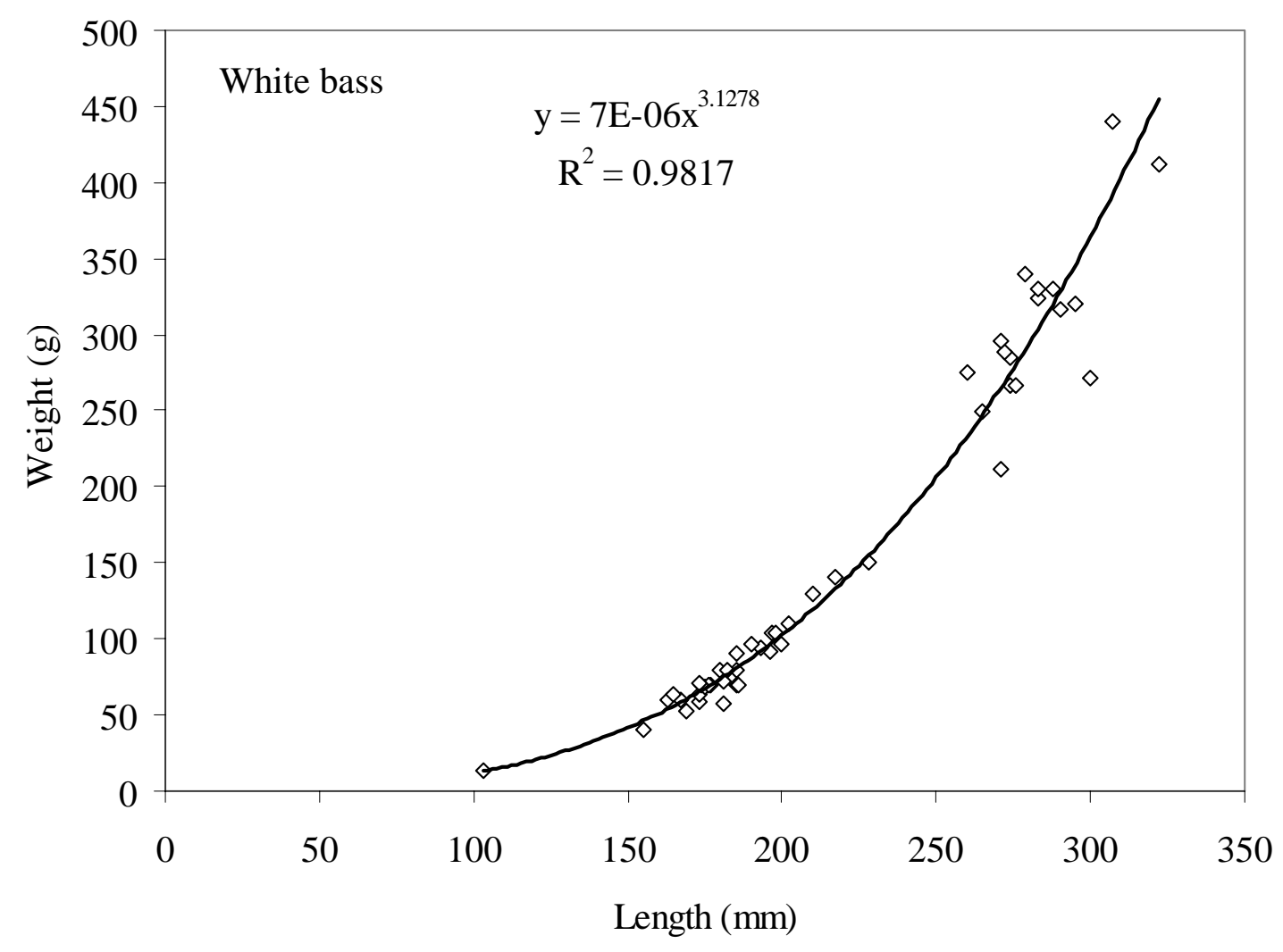


Table 4. Mean length-at-age of channel catfish, freshwater drum, and white bass collected in the Belleville Pool, Ohio River during February 17 through April 7, 2002 and December 12, 2002 through March 17, 2003. Variances are in parentheses; no values indicate only one individual for that age group was collected.

Mean length $(\mathrm{cm})$

\begin{tabular}{crrrrrr} 
Age & \multicolumn{2}{c}{$\begin{array}{c}\text { Channel } \\
\text { catfish }\end{array}$} & \multicolumn{2}{c}{$\begin{array}{c}\text { Freshwater } \\
\text { drum }\end{array}$} & \multicolumn{2}{c}{$\begin{array}{c}\text { White } \\
\text { bass }\end{array}$} \\
\hline 0 & 23.8 & $(9.7)$ & 5.5 & $(0.5)$ & & \\
1 & 24.8 & $(39.7)$ & 8.0 & $(1.6)$ & 11.2 & \\
2 & 35.6 & $(19.4)$ & 17.3 & $(8.2)$ & 18.8 & $(3.4)$ \\
3 & 38.4 & $(40.7)$ & 23.8 & $(2.5)$ & 27.8 & $(0.8)$ \\
4 & 45.6 & $(37.8)$ & 28.6 & $(5.6)$ & 30.4 & $(1.3)$ \\
5 & 50.5 & $(55.5)$ & 31.6 & $(5.4)$ & & \\
6 & 54.0 & $(53.2)$ & 37.9 & $(8.1)$ & & \\
7 & 56.8 & $(46.8)$ & 45.0 & $(27.6)$ & & \\
8 & 59.2 & & 44.8 & $(63.6)$ & & \\
9 & 62.0 & $(32.0)$ & 48.7 & $(5.9)$ & & \\
10 & & & 49.0 & $(32.0)$ & & \\
11 & & & 48.0 & $(36.0)$ & & \\
12 & & & 54.7 & $(21.2)$ & & \\
13 & & & 58.7 & $(37.3)$ & & \\
14 & & & 61.0 & $(8.0)$ & & \\
16 & & & 59.0 & & & \\
17 & & & 61.0 & $(18.0)$ & & \\
18 & & & 66.0 & & & \\
22 & & & 77.0 & & & \\
\hline
\end{tabular}




\section{SUMMARY}

Winter is a critical period during which fishes suffer increased mortality. During winter conditions, fishes select refuge habitats where physiochemical factors are unlikely to exceed tolerance limits. In large temperate river systems, such as the Ohio River, extremely low water temperatures during winter coupled with high flows could be expected to increase mortality rates of fishes. Juvenile fishes are most susceptible to winter mortality due to their small size and lack of energy reserves. The greatest diversity and abundance of fishes were collected by electrofishing in the Belleville Pool, Ohio River, in low-velocity tributary confluences and an embayment at temperatures $>3$ - $4{ }^{\circ} \mathrm{C}$. When water temperatures were $<3{ }^{\circ} \mathrm{C}$, more individuals of certain species were collected in faster-velocity main channel and back channel habitats. Other species collected at temperatures $<3{ }^{\circ} \mathrm{C}$ continued to associate with the lower flows in tributaries. The lack of water temperatures $>4{ }^{\circ} \mathrm{C}$ in tributaries may have left some fishes susceptible to current velocity, which carried them into channel habitats.

Species- and age-specific responses to winter conditions may obscure broad generalizations about when and how certain species use overwintering refuges. For example, in the Little Sandy Creek embayment, adjacent to the Belleville Pool, 85\% of all fishes collected were juveniles. Centrarchids, popular sport fishes, while collected in low numbers in the mainstem portion of the river, were one of the dominant fishes collected in the embayment. Protecting and modifying embayment habitats may reduce juvenile mortality during winter and improve recreational angling opportunities for sunfish in large river systems 
Populations of channel catfish, Ictalurus punctatus, and freshwater drum, Aplodinotus grunniens, the most abundant fishes collected in the Belleville Pool, exhibit satisfactory population growth and condition. Channel catfish reach larger mean-lengths at all ages compared to specimens collected over 30 years ago in the Belleville Pool. Numerous older and larger freshwater drum individuals were collected, suggesting plentiful trophy-sized individuals exist in the Ohio River. Conversely, none of the white bass, Morone chrysops, individuals collected were harvestable size. Fishery managers can use this information to assess the population growth and condition of these three species and make management decisions according to their goals for each species. Possibly, the population growth and the probability of survival of fishes of all ages may increase by protecting and enhancing tributary and embayment habitats in large rivers during winter. 


\section{APPENDIX A}

Fish caught per hour (CPUE) within each habitat type in the Belleville Pool, Ohio River. No values indicate habitat not sampled. 


\begin{tabular}{|c|c|c|c|c|c|c|c|}
\hline \multicolumn{8}{|l|}{ February 2002 session } \\
\hline \multirow[b]{3}{*}{ Species } & \multicolumn{4}{|c|}{ Habitat types } & \\
\hline & \multicolumn{2}{|c|}{ Island } & \multirow{2}{*}{$\begin{array}{c}\text { Back } \\
\text { channel }\end{array}$} & \multirow{2}{*}{$\begin{array}{c}\text { Main } \\
\text { channel }\end{array}$} & \multirow[b]{2}{*}{ Trib } & \multirow{2}{*}{$\begin{array}{l}\text { Deep } \\
\text { hole }\end{array}$} & \multirow[b]{2}{*}{ Total } \\
\hline & Head & Tail & & & & & \\
\hline Emerald Shiner & \multicolumn{4}{|c|}{0} & 1.6 & 0 & 1.0 \\
\hline Freshwater Drum & \multicolumn{4}{|c|}{0} & 6.5 & 0 & 4.2 \\
\hline Gizzard Shad & \multicolumn{4}{|c|}{0} & 68.5 & 0 & 43.6 \\
\hline River Carpsucker & \multicolumn{4}{|c|}{0} & 1.6 & 0 & 1.0 \\
\hline Total & \multicolumn{4}{|c|}{0} & 78.3 & 0 & 49.8 \\
\hline \multicolumn{8}{|l|}{ March 2002 session } \\
\hline & \multicolumn{4}{|c|}{ Habitat types } & & & \\
\hline & \multicolumn{2}{|c|}{ Island } & Back & \multirow{2}{*}{$\begin{array}{c}\text { Main } \\
\text { channel }\end{array}$} & \multicolumn{3}{|c|}{ Deep } \\
\hline Species & Head & Tail & channel & & Trib & hole & Total \\
\hline Channel Catfish & 4.4 & 0 & 3.2 & 1.1 & 65.4 & 0 & 11.1 \\
\hline Common Carp & 0 & 0 & 0 & 0 & 3.9 & 0 & 0.6 \\
\hline Emerald Shiner & 0 & 0 & 0 & 0 & 2.9 & 0 & 0.4 \\
\hline Freshwater Drum & 0 & 0 & 0.8 & 2.8 & 129.8 & 0 & 20.8 \\
\hline Gizzard Shad & 0 & 0 & 0 & 0 & 12.7 & 0 & 1.9 \\
\hline Hybrid Striped Bass & 0 & 0 & 0 & 0 & 3.9 & 0 & 0.6 \\
\hline Mooneye & 0 & 3.0 & 0 & 0 & 2.0 & 0 & 0.7 \\
\hline Quillback & 0 & 0 & 0 & 0 & 2.0 & 0 & 0.3 \\
\hline River Carpsucker & 0 & 0 & 0 & 0 & 3.9 & 0 & 0.6 \\
\hline Walleye & 0 & 0 & 0 & 0 & 2.0 & 0 & 0.3 \\
\hline Total & 4.4 & 3.0 & 4.0 & 3.9 & 228.3 & 0 & 37.3 \\
\hline \multicolumn{8}{|c|}{ Early April 2002 session } \\
\hline & \multicolumn{4}{|c|}{ Habitat types } & & & \\
\hline & \multicolumn{2}{|c|}{ Island } & Back & Main & & Deep & \\
\hline Species & Head & Tail & channel & channel & Trib & hole & Total \\
\hline Channel Catfish & 0 & 1.7 & 5.6 & 2.9 & 0 & 0 & 2.9 \\
\hline Emerald Shiner & 0 & 0 & 0 & 0 & 1.5 & 0 & 0.1 \\
\hline Flathead Catfish & 0 & 0 & 0 & 0.3 & 0 & 0 & 0.1 \\
\hline Freshwater Drum & 0 & 0 & 0.6 & 0.3 & 21.4 & 0 & 2.2 \\
\hline Gizzard Shad & 0 & 0 & 0 & 0 & 3.1 & 0 & 0.3 \\
\hline Highfin Carpsucker & 0 & 0 & 0 & 0 & 3.1 & 0 & 0.3 \\
\hline Mooneye & 0 & 0 & 0.6 & 0 & 0 & 0 & 0.1 \\
\hline River Carpsucker & 0 & 0 & 0 & 0 & 6.1 & 0 & 0.6 \\
\hline Total & 0 & 1.7 & 6.7 & 3.5 & 35.2 & 0 & 6.7 \\
\hline
\end{tabular}




\begin{tabular}{|c|c|c|c|c|c|c|c|}
\hline \multicolumn{8}{|l|}{ Mid-April 2002 Session } \\
\hline \multirow[b]{3}{*}{ Species } & \multicolumn{4}{|c|}{ Habitat types } & \\
\hline & \multicolumn{2}{|c|}{ Island } & \multirow{2}{*}{$\begin{array}{c}\text { Back } \\
\text { channel }\end{array}$} & \multirow{2}{*}{$\begin{array}{c}\text { Main } \\
\text { channel }\end{array}$} & \multirow[b]{2}{*}{ Trib } & \multirow{2}{*}{$\begin{array}{c}\text { Deep } \\
\text { hole }\end{array}$} & \multirow[b]{2}{*}{ Total } \\
\hline & Head & Tail & & & & & \\
\hline Bluegill & 0 & 0 & 0 & 0 & 1.7 & 0 & 0.2 \\
\hline Channel Catfish & 7.1 & 1.8 & 2.1 & 2.2 & 13.1 & 0 & 3.6 \\
\hline Emerald Shiner & 0 & 0 & 0 & 0 & 4.9 & 0 & 0.5 \\
\hline Freshwater Drum & 5.3 & 3.5 & 1.4 & 0.4 & 14.8 & 0 & 2.8 \\
\hline Gizzard Shad & 0 & 0 & 0 & 0.4 & 0 & 0 & 0.2 \\
\hline Mooneye & 0 & 0 & 0 & 0.4 & 0 & 0 & 0.2 \\
\hline Orangespotted Sunfish & 0 & 0 & 0 & 0 & 1.6 & 0 & 0.2 \\
\hline River Carpsucker & 0 & 0 & 0 & 0 & 9.8 & 0 & 1.0 \\
\hline Total & 12.4 & 5.3 & 3.5 & 3.3 & 46.0 & 0 & 8.5 \\
\hline \multicolumn{8}{|c|}{ February - April 2002 sessions total } \\
\hline \multicolumn{8}{|c|}{ Habitat types } \\
\hline & \multicolumn{2}{|c|}{ Island } & Back & Main & & Deep & \\
\hline Species & Head & Tail & channel & channel & Trib & hole & Total \\
\hline Bluegill & 0 & 0 & 0 & 0 & 0.3 & 0 & 0.1 \\
\hline Channel catfish & 4.1 & 1.9 & 3.8 & 2.1 & 25.8 & 0 & 5.8 \\
\hline Common carp & 0 & 0 & 0 & 0 & 1.4 & 0 & 0.2 \\
\hline Emerald shiner & 0 & 0 & 0 & 0 & 2.8 & 0 & 0.4 \\
\hline Flathead catfish & 0 & 0 & 0 & 0.1 & 0 & 0 & 0.1 \\
\hline Freshwater drum & 2.0 & 0.9 & 0.9 & 1.1 & 55.1 & 0 & 8.6 \\
\hline Gizzard shad & 0 & 0 & 0 & 0.1 & 19.6 & 0 & 2.8 \\
\hline Highfin carpsucker & 0 & 0 & 0 & 0 & 0.7 & 0 & 0.1 \\
\hline Hybrid striped bass & 0 & 0 & 0 & 0 & 1.4 & 0 & 0.2 \\
\hline Mooneye & 0 & 1.4 & 0.2 & 0.1 & 0.7 & 0 & 0.3 \\
\hline Orangespotted Sunfish & 0 & 0 & 0 & 0 & 0.3 & 0 & 0.1 \\
\hline Quillback & 0 & 0 & 0 & 0 & 0.7 & 0 & 0.1 \\
\hline River carpsucker & 0 & 0 & 0 & 0 & 5.2 & 0 & 0.7 \\
\hline Walleye & 0 & 0 & 0 & 0 & 1.0 & 0 & 0.1 \\
\hline Total & 6.1 & 4.2 & 4.9 & 3.6 & 114.7 & 0 & 19.6 \\
\hline
\end{tabular}




\begin{tabular}{|c|c|c|c|c|c|c|c|c|}
\hline \multicolumn{9}{|l|}{ December 2002 session } \\
\hline \multirow[b]{3}{*}{ Species } & \multicolumn{6}{|c|}{ Habitat types } & \multirow{3}{*}{$\begin{array}{c}\text { Embay- } \\
\text { ment }\end{array}$} & \multirow[b]{3}{*}{ Tota } \\
\hline & \multicolumn{2}{|c|}{ Island } & \multirow{2}{*}{$\begin{array}{c}\text { Back } \\
\text { channel }\end{array}$} & \multirow{2}{*}{$\begin{array}{c}\text { Main } \\
\text { channel }\end{array}$} & \multirow[b]{2}{*}{ Trib } & \multirow{2}{*}{$\begin{array}{l}\text { Deep } \\
\text { hole }\end{array}$} & & \\
\hline & Head & Tail & & & & & & \\
\hline Black Crappie & 0 & 0 & 0 & 0 & 0 & 0 & 1.8 & 0.1 \\
\hline Bluegill & 0 & 0 & 0 & 0 & 0 & 0 & 198.3 & 13.1 \\
\hline Channel Catfish & 0 & 0 & 2.6 & 7.0 & 0 & 2.7 & 0 & 3.2 \\
\hline Common Carp & 0 & 0 & 0.4 & 0 & 0 & 0 & 0 & 0.1 \\
\hline Emerald Shiner & 0 & 0 & 0 & 0 & 0 & 0 & 210.5 & 13.9 \\
\hline Freshwater Drum & 0 & 1.0 & 5.6 & 10.4 & 0 & 8.2 & 7.0 & 6.1 \\
\hline Gizzard Shad & 0 & 0 & 0 & 0.4 & 0 & 0 & 708.8 & 46.9 \\
\hline Green Sunfish & 0 & 0 & 0 & 0 & 0 & 0 & 5.3 & 0.4 \\
\hline Mooneye & 0 & 1.9 & 1.5 & 0 & 0 & 0 & 0 & 0.7 \\
\hline Mosquitofish & 0 & 0 & 0 & 0 & 0 & 0 & 1.8 & 0.1 \\
\hline Ohio Lamprey & 0 & 0 & 0.4 & 0 & 0 & 0 & 0 & 0.1 \\
\hline Orangespotted Sunfish & 0 & 0 & 0 & 0 & 0 & 0 & 61.4 & 4.1 \\
\hline River Carpsucker & 0 & 0 & 0 & 0.4 & 0 & 0 & 0 & 0.1 \\
\hline Sauger & 0 & 1.0 & 0 & 0 & 0 & 0 & 0 & 0.1 \\
\hline Silver Chub & 0 & 6.7 & 0.4 & 1.7 & 0 & 0 & 0 & 1.2 \\
\hline Smallmouth Buffalo & 0 & 1.0 & 0.7 & 0.4 & 0 & 0 & 0 & 0.5 \\
\hline Spotted Bass & 0 & 0 & 0 & 0 & 0 & 5.5 & 0 & 0.2 \\
\hline Spotted Sucker & 0 & 0 & 0 & 0 & 0 & 0 & 1.8 & 0.1 \\
\hline Warmouth & 0 & 0 & 0 & 0 & 0 & 0 & 3.5 & 0.2 \\
\hline White Bass & 0 & 0 & 0.4 & 0 & 0 & 0 & 0 & 0.1 \\
\hline White Crappie & 0 & 0 & 0 & 0 & 0 & 0 & 57.9 & 3.7 \\
\hline Total & 0 & 11.4 & 11.9 & 20.2 & 0 & 16.4 & 1257.9 & 95.0 \\
\hline
\end{tabular}




\begin{tabular}{lccccccc}
\hline January 2003 session & \multicolumn{7}{c}{ Habitat types } \\
\multicolumn{1}{l}{ Island } & Back & Main & & Deep \\
Species & Head & Tail & channel & channel & Trib & hole & Total \\
\hline Black Buffalo & 0 & 0 & 0 & 0 & 0 & 0 & 0.1 \\
Black Crappie & 0 & 0 & 0 & 0 & 0.9 & 0 & 0.1 \\
Channel Catfish & 0 & 0 & 1.1 & 1.3 & 6.4 & 0 & 1.6 \\
Common Carp & 0 & 1.4 & 0.7 & 0 & 1.8 & 0 & 0.7 \\
Emerald Shiner & 0 & 0 & 0 & 0 & 0 & 0 & 0.2 \\
Freshwater Drum & 0 & 0 & 1.8 & 3.0 & 50.9 & 0 & 8.7 \\
Gizzard Shad & 0 & 0 & 0.4 & 0 & 0.9 & 0 & 0.3 \\
Golden Redhorse & 0 & 0 & 0 & 0 & 0.9 & 0 & 0.1 \\
Highfin Carpsucker & 0 & 0 & 0 & 0 & 1.8 & 0 & 0.2 \\
Hybrid Striped Bass & 0 & 0 & 0 & 0 & 3.0 & 0 & 0.3 \\
Mooneye & 0 & 0 & 0 & 0.7 & 0 & 0 & 0.2 \\
Quillback & 0 & 0 & 0 & 0 & 0.9 & 0 & 0.1 \\
River Carpsucker & 0 & 0 & 0 & 0 & 3.6 & 0 & 0.6 \\
Rock Bass & 0 & 0 & 0.4 & 0 & 0 & 0 & 0.1 \\
Sauger & 0 & 0 & 0 & 0 & 0.9 & 0 & 0.1 \\
Shorthead Redhorse & 0 & 0 & 0 & 0.3 & 0 & 0 & 0.2 \\
Silver Chub & 0 & 0 & 0.4 & 0 & 0 & 0 & 0.1 \\
Smallmouth Buffalo & 0 & 0 & 1.4 & 1.0 & 24.5 & 0 & 5.2 \\
White Bass & 0 & 0 & 0 & 0.3 & 30.9 & 0 & 4.1 \\
Total & 0 & 1.4 & 6.0 & 6.7 & 127.3 & 0 & 23.1 \\
\hline
\end{tabular}




\begin{tabular}{|c|c|c|c|c|c|c|c|c|}
\hline \multicolumn{9}{|l|}{ March 2003 session } \\
\hline \multirow[b]{3}{*}{ Species } & \multicolumn{6}{|c|}{ Habitat types } & \multirow{3}{*}{$\begin{array}{c}\text { Embay- } \\
\text { ment }\end{array}$} & \multirow[b]{3}{*}{ Total } \\
\hline & \multicolumn{2}{|c|}{ Island } & \multirow{2}{*}{$\begin{array}{c}\text { Back } \\
\text { channel }\end{array}$} & \multirow{2}{*}{$\begin{array}{c}\text { Main } \\
\text { channel }\end{array}$} & \multirow[b]{2}{*}{ Trib } & \multirow{2}{*}{$\begin{array}{c}\text { Deep } \\
\text { hole }\end{array}$} & & \\
\hline & Head & Tail & & & & & & \\
\hline Black Crappie & 0 & 0 & 0 & 0 & 0 & 0 & 1.1 & 0.1 \\
\hline Bluegill & 0 & 0 & 0 & 0 & 0 & 0 & 56.9 & 5.5 \\
\hline Bowfin & 0 & 0 & 0 & 0 & 0 & 0 & 1.1 & 0.1 \\
\hline Channel Catfish & 0 & 0 & 6.7 & 4.5 & 4.5 & 0 & 0.0 & 3.9 \\
\hline Common Carp & 0 & 0 & 0 & 0.6 & 0 & 0 & 3.4 & 0.5 \\
\hline Emerald Shiner & 0 & 0 & 0 & 0 & 0 & 0 & 19.0 & 1.8 \\
\hline Freshwater Drum & 0 & 0 & 0.8 & 34.1 & 40.3 & 0 & 2.2 & 17.6 \\
\hline Gizzard Shad & 0 & 0 & 0.4 & 3.5 & 1.5 & 0 & 29.0 & 4.3 \\
\hline Green Sunfish & 0 & 0 & 0 & 0 & 0 & 0 & 4.5 & 0.4 \\
\hline Hybrid Striped Bass & 0 & 0 & 0 & 1.9 & 5.2 & 0 & 0 & 1.4 \\
\hline Largemouth Bass & 0 & 0 & 0 & 0 & 0 & 0 & 3.4 & 0.3 \\
\hline Mooneye & 0 & 0 & 0.8 & 0.3 & 0 & 0 & 0 & 0.3 \\
\hline Orangespotted Sunfish & 0 & 0 & 0 & 0 & 0 & 0 & 15.6 & 1.5 \\
\hline Pumpkinseed & 0 & 0 & 0 & 0 & 0 & 0 & 5.6 & 0.5 \\
\hline Quillback & 0 & 0 & 0 & 0 & 0.8 & 0 & 0 & 0.1 \\
\hline River Carpsucker & 0 & 0 & 0.8 & 0.3 & 1.5 & 0 & 4.5 & 1.0 \\
\hline Sauger & 0 & 0 & 0 & 0 & 0.8 & 0 & 0 & 0.1 \\
\hline Silver Chub & 0 & 0 & 0.4 & 0.3 & 0 & 0 & 0 & 0.2 \\
\hline Smallmouth Buffalo & 0 & 1.5 & 1.7 & 2.3 & 2.2 & 0 & 1.1 & 1.7 \\
\hline Spotted Sucker & 0 & 0 & 0 & 0 & 0 & 0 & 1.1 & 0.1 \\
\hline Walleye & 0 & 0 & 0 & 0 & 0.8 & 0 & 0 & 0.1 \\
\hline Warmouth & 0 & 0 & 0 & 0 & 0 & 0 & 3.4 & 0.3 \\
\hline White Bass & 1.6 & 0 & 0.8 & 1.0 & 2.2 & 0 & 0 & 1.0 \\
\hline White Crappie & 0 & 0 & 0 & 0.3 & 0 & 0 & 41.3 & 4.1 \\
\hline Total & 1.6 & 1.5 & 12.6 & 49.2 & 59.6 & 0 & 193.1 & 46.9 \\
\hline
\end{tabular}




\begin{tabular}{|c|c|c|c|c|c|c|c|c|c|}
\hline \multicolumn{10}{|c|}{ December 2002-March 2003 sessions total } \\
\hline \multirow[b]{3}{*}{ Species } & \multicolumn{6}{|c|}{ Habitat types } & \multirow{3}{*}{$\begin{array}{c}\text { Wing } \\
\text { dam }\end{array}$} & \multirow{3}{*}{$\begin{array}{c}\text { Embay- } \\
\text { ment }\end{array}$} & \multirow[b]{3}{*}{ Tota } \\
\hline & \multicolumn{2}{|c|}{ Island } & \multirow{2}{*}{$\begin{array}{c}\text { Back } \\
\text { channel }\end{array}$} & \multirow{2}{*}{$\begin{array}{c}\text { Main } \\
\text { channel }\end{array}$} & \multirow[b]{2}{*}{ Trib } & \multirow{2}{*}{$\begin{array}{c}\text { Deep } \\
\text { hole }\end{array}$} & & & \\
\hline & Head & Tail & & & & & & & \\
\hline Black Buffalo & 0 & 0 & 0 & 0 & 0 & 0 & 7.5 & 0 & 0.04 \\
\hline Black Crappie & 0 & 0 & 0 & 0 & 0.3 & 0 & 0 & 1.4 & 0.1 \\
\hline Bluegill & 0 & 0 & 0 & 0 & 0 & 0 & 0 & 111.9 & 6.1 \\
\hline Bowfin & 0 & 0 & 0 & 0 & 0 & 0 & 0 & 0.7 & 0.04 \\
\hline Channel Catfish & 0 & 0 & 3.3 & 4.8 & 4.1 & 0.9 & 0 & 0 & 3.1 \\
\hline Common Carp & 0 & 0.5 & 0.4 & 0.2 & 0.6 & 0 & 7.5 & 2.1 & 0.5 \\
\hline Emerald Shiner & 0 & 0 & 0 & 0 & 0 & 0 & 15.0 & 93.5 & 5.2 \\
\hline Freshwater Drum & 0 & 0.5 & 2.8 & 16.3 & 34.8 & 2.6 & 52.6 & 4.1 & 11.0 \\
\hline Gizzard Shad & 0 & 0 & 0.3 & 1.3 & 1.0 & 0 & 7.5 & 293.3 & 16.7 \\
\hline Golden Redhorse & 0 & 0 & 0 & 0 & 0.3 & 0 & 0 & 0 & 0.04 \\
\hline Green Sunfish & 0 & 0 & 0 & 0 & 0 & 0 & 0 & 4.8 & 0.3 \\
\hline Highfin Carpsucker & 0 & 0 & 0 & 0 & 0.6 & 0 & 0 & 0 & 0.1 \\
\hline Hybrid Striped Bass & 0 & 0 & 0 & 0.7 & 3.2 & 0 & 0 & 0 & 0.6 \\
\hline Largemouth Bass & 0 & 0 & 0 & 0.1 & 0 & 0 & 0 & 2.1 & 0.2 \\
\hline Mooneye & 0 & 0.9 & 0.8 & 0.3 & 0 & 0 & 0 & 0 & 0.4 \\
\hline Mosquitofish & 0 & 0 & 0 & 0 & 0 & 0 & 0 & 0.7 & 0.04 \\
\hline Ohio Lamprey & 0 & 0 & 0.1 & 0 & 0 & 0 & 0 & 0 & 0.04 \\
\hline Orangespotted Sunfish & 0 & 0 & 0 & 0 & 0 & 0 & 0 & 33.4 & 1.8 \\
\hline Pumpkinseed & 0 & 0 & 0 & 0 & 0 & 0 & 0 & 3.4 & 0.2 \\
\hline Quillback & 0 & 0 & 0 & 0 & 0.6 & 0 & 0 & 0 & 0.1 \\
\hline River Carpsucker & 0 & 0 & 0.3 & 0.2 & 1.9 & 0 & 7.5 & 2.7 & 0.6 \\
\hline Rock Bass & 0 & 0 & 0.1 & 0 & 0 & 0 & 0 & 0 & 0.04 \\
\hline Sauger & 0 & 0.5 & 0 & 0 & 0.6 & 0 & 0 & 0 & 0.1 \\
\hline Shorthead Redhorse & 0 & 0 & 0 & 0.1 & 0 & 0 & 7.5 & 0 & 0.1 \\
\hline Silver Chub & 0 & 1.8 & 0.5 & 0.7 & 0 & 0 & 0 & 0 & 0.5 \\
\hline Smallmouth Buffalo & 0 & 0.9 & 1.3 & 1.3 & 9.5 & 0 & 90.2 & 0.7 & 2.5 \\
\hline Spotted Bass & 0 & 0 & 0 & 0 & 0 & 1.7 & 0 & 0 & 0.1 \\
\hline Spotted Sucker & 0 & 0 & 0 & 0 & 0 & 0 & 0 & 1.4 & 0.1 \\
\hline Walleye & 0 & 0 & 0 & 0 & 0.3 & 0 & 0 & 0 & 0.04 \\
\hline Warmouth & 0 & 0 & 0 & 0 & 0 & 0 & 0 & 3.4 & 0.2 \\
\hline White Bass & 0.5 & 0 & 0.4 & 0.4 & 11.7 & 0 & 7.5 & 0 & 1.7 \\
\hline White Crappie & 0 & 0 & 0 & 0.1 & 0 & 0 & 0 & 47.8 & 2.6 \\
\hline Total & 0.5 & 5.0 & 10.1 & 26.6 & 69.6 & 5.2 & 203.0 & 607.1 & 54.9 \\
\hline
\end{tabular}




\section{VITA}

November 7, 1975...........................Born - Pullman, Washington

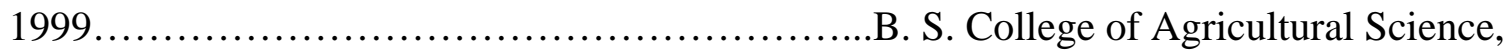
University of Wisconsin-Madison

2001-present. ..Graduate Research Assistant, West Virginia University

\section{PRESENTATIONS}

Lenz, B., S. Welsh, K. Hartman. Winter habitats of fishes in the Ohio River. Presented at the American Fisheries Society annual meeting, Quebec City, Canada, 12 August 2003.

Lenz, B., S. Welsh, K. Hartman. Winter habitats of fishes in the Belleville Pool, Ohio River. Presented at the West Virginia Cooperative Fish and Wildlife Unit annual meeting, Morgantown, WV, 24 April 2003.

Lenz, B., S. Welsh, K. Hartman. Winter habitats of channel catfish and freshwater drum in the Belleville Pool, Ohio River. Presented at the Wildlife Society annual meeting, Morgantown, WV, 6 March 2003.

Lenz, B., S. Welsh, K. Hartman. Winter habitats of channel catfish and freshwater drum in the Belleville Pool, Ohio River. Presented at the Tri-State (Kentucky, Virginia and West Virginia) annual meeting, Ashland, KY, 5 March 2003.

Lenz, B., S. Welsh, K. Hartman. Winter habitats of channel catfish and freshwater drum in the Belleville Pool, Ohio River. Presented at the Southern Division of the American Fisheries Society annual meeting, Wilmington, NC, 16 February 2003.

\section{FIELDS OF STUDY}

Major Field: Zoology

Specialization: Aquatic Ecology 